\title{
Small vertebrates from a Holocene gravelly deposit at El Salt (Alcoi, Alicante)
}

\author{
Ana FAGOAGA ${ }^{1,2^{*}}$, Rafael MARQUINA-BLASCO ${ }^{1,2}$, Daniel GRACIA-MONFERRER ${ }^{1}$, Alberto \\ MARTÍNEZ-ORTII', ${ }^{1,2}$ Paloma VIDAL-MATUTANO ${ }^{3}$, Laura SÁNCHEZ-LÓPEZ ${ }^{1}$, Carolina \\ MALLOL ${ }^{4}$, Cristo M. HERNÁNDEZ4, Bertila GALVÁN ${ }^{4}$, Salvador BAILON ${ }^{5}$, Francisco J. \\ RUIZ-SÁNCHEZ ${ }^{1,2,6} \&$ César LAPLANA
}

\footnotetext{
${ }^{1}$ Universitat de València, Burjassot, Spain. ana.fagoaga@uv.es; rafael.marquina@uv.es; dani.gracios@gmail.com; sanlolau@ alumni.es; francisco.ruiz@uv.es

${ }^{2}$ Museu Valencià d'Història Natural \& ilBiotaxa. amorti@uv.es

${ }^{3}$ Universidad de Las Palmas de Gran Canaria, Las Palmas de Gran Canaria, Spain. paloma.vidal@ulpgc.es

${ }^{4}$ Universidad de La Laguna, San Cristóbal de La Laguna, Spain. cmallol@ull.edu.es; chergomw@gmail.com; bgalvan@ull.es

${ }^{5}$ Sorbonne Universités, MNHN-CNRS, Paris, France. salvador.bailon@mnhn.fr

${ }^{6}$ Universidad Estatal Península de Santa Elena, Santa Elena, Ecuador.

${ }^{7}$ Museo Arqueológico de la Comunidad de Madrid, Alcalá de Henares, Spain. cesar.laplana@gmail.com
}

*Corresponding author

Fagoaga, A., Marquina-Blasco, R., Gracia-Monferrer, D., Martínez-Ortí, A., Vidal-Matutano, P., Sánchez-López, L., Mallol, C., Hernández, C.M., Galván, B., Bailon, S., Ruiz-Sánchez, F.J. \& Laplana, C. 2021. Small vertebrates from a Holocene gravelly deposit at El Salt (Alcoi, Alicante). [Pequeños vertebrados del depósito de gravas del Holoceno de El Salt (Alcoi, Alicante)]. Spanish Journal of Palaeontology, 36 (1), 51-76.

\begin{abstract}
The small-vertebrates' assemblage recovered comes from Units I to IV from El Salt site (Alcoi, Spain). The sample is composed by nearly 310 remains, and includes one toad (Epidalea calamita), two lizards (Lacertidae indet. and Chalcides cf. bedriagai), two snakes (Coronella $\mathrm{cf}$. girondica and cf. Coronella sp.), two insectivores (Crocidura sp. and Sorex sp.), one lagomorph (Oryctolagus cuniculus) and seven rodent taxa (Arvicola sapidus, Microtus sp., M. arvalis, M. cabrerae, M. duodecimcostatus, Apodemus sylvaticus, and Eliomys quercinus). All the species described in the present work are consistent with a Late Pleistocene-Holocene
\end{abstract}

\section{RESUMEN}

El conjunto de pequeños vertebrados recuperado procede de las Unidades I a IV del yacimiento de El Salt. Esta muestra se compone de casi 310 restos e incluye un sapo (Epidalea calamita), dos lagartos (Lacertidae indet. y Chalcides $\mathrm{cf}$. bedriagai), dos serpientes (Coronella cf. girondica y cf. Coronella sp.), dos insectívoros (Crocidura sp. y Sorex sp.), un lagomorfo (Oryctolagus cuniculus) y siete taxones de roedores (Arvicola sapidus, Microtus sp., M. arvalis, M. cabrerae, M. duodecimcostatus, Apodemus sylvaticus y Eliomys quercinus). Todas las especies descritas en el presente trabajo son consistentes con una cronología del Pleistoceno 
chronology. The presence of M. cabrerae (absent in the Middle Pleistocene) and M. duodecimcostatus (absent in the Mediterranean until the Late Pleistocene) seem to confirm this age. The presence of Neolithic pottery and M. arvalis in the same deposit is inconsistent from a biochronically point of view since this species was extirpated from this region at the end of the Late Pleistocene. Several taphonomic alterations related to transport within the small mammal remains have been identified. Further taphonomical and geoarchaeological work is needed to clarify the provenience of the studied faunal assemblages, which, given the high energy, erosional morphology and lithology of the sedimentary deposit, could have been reworked in a more recent time period.

Keywords: Iberian Peninsula, small mammals, herpetofauna, Biochronology, Quaternary.
Superior-Holoceno. La presencia de $M$. cabrerae (ausente en el Pleistoceno Medio) y M. duodecimcostatus (ausente en el área mediterránea hasta el Pleistoceno Superior) confirman esta edad. La asociación de cerámica neolítica y la especie $M$. arvalis en el mismo depósito es inconsistente desde el punto de vista biocronológico, ya que esta especie desaparece en la región a finales del Pleistoceno Superior. Se han identificado varias alteraciones tafonómicas relacionadas con el transporte entre los pequeños restos de mamíferos. Son necesarios trabajos tafonómicos y geoarqueológicos en mayor profundidad para aclarar la procedencia de los conjuntos de fauna estudiados, que, dada la alta energía, la morfología erosiva y la litología del depósito sedimentario, podrían haberse reelaborado en períodos de tiempo más recientes.

Palabras clave: Península Ibérica, pequeños mamíferos, herpetofauna, Biocronología, Cuaternario.

\section{INTRODUCTION}

Biochronology establishes a temporal context based on the palaeobiological species and assemblages, and proposes "the organization of geologic time according to the irreversible process of organic evolution" (Berggren \& Van Couvering, 1978). Thus, this concept relates biological events to the geological time scale (Lindsay, 2003). In this sense, small mammals are considered as a key tool for the definition of the biochronology in continental sites of the Paleogene (MP zones, Schmidt-Kittler, 1987; Aguilar et al., 1997), Neogene (MN zones, Mein, 1975), and Early Quaternary (MmQ zones, Agustí et al., 1987). The abundance, high evolution rates and broad distribution of the small mammals, and the relatively easy recovery process, make these animals perfect for this purpose (López-Martínez \& Truyols-Santonja, 1994).

There is a clear relationship between biochronology, biostratigraphy and taphonomic processes operating on the fossil record (Fernández López, 1991). Among others, post-depositional processes are highly important during fossilization, affecting to this relationship. In this sense, this kind of alterations must be detected. For example, reworked remains are exhumed from their original sediment and reburied in a new layer (Fernández López, 1991; Donovan et al., 2010). Examples of this kind of finds are numerous in the specialized literature (i.e., Donovan et al., 2010; Hontecillas et al., 2015; Crespo et al., 2016). Within those examples, the karstic reactivation recorded in the central Mediterranean area around $6 \mathrm{ka}$ BP (Northgrippian, Holocene) has been related to erosive events in numerous sites of the region (Fumanal, 1986, 1995), requiring the conduction of taphonomic analysis to avoid erroneous biochronological conclusions.
The central Mediterranean area of the Iberian Peninsula (Comunitat Valenciana) has yielded several Quaternary sites. Some of them are adscribed to the final part of the Late Pleistocene and to the Holocene (Badal \& Carrión, 2001), and just a few carry out the study of the small vertebrates. Among them, Late Pleistocene small-mammal fossils have been reported from Cueva de San Antón (Sarrión, 1983), Cova Matutano (Nadal, 1998), Cova del Bolomor, Cova Negra (Guillem, 2001) and Cingle de l'Aigua (Villaverde et al., 2010), among others. Other works are centered in Pleistocene but also Holocene levels. These are the case for Tossal de la Roca (Cacho et al., 1995), Cova de les Cendres (Guillem, 2001; Tormo-Cuñat, 2010) and Cova Fosca (Sesé, 2011) among other sites. Moreover, small mammals from Holocene deposits have also been studied in Cova del Barranc Fondo (Boessneck, 1974), Cova de la Sarsa (Sevilla, 1988), Cova Bolumini (Guillem et al., 1992), Cova de l'Or (Arribas, 2004) and Abric de la Falguera (Guillem, 2006) among other sites. The small mammal assemblages recorded at these sites show a shift from Late Pleistocene open landscapes to Holocene forest expansion and, posteriorly, landscape modifications related with agriculture and livestock exploitation by humans. In this sense, at mid-Holocene and related to human impact on environment and species, human migrations facilitated the introduction and dispersal of several species of small mammals (Cuchi et al., 2005; Domínguez García et al., 2019).

Regarding the herpetofauna, there have been very few studies focusing on this period. Most of them do not include data on the Late Pleistocene and commonly, herpetofauna is only anecdotally recorded within taxonomic lists in some Holocene sites: Cabezo Redondo (von de Driesch \& Boessneck, 1969), Los Saladares (von des Driesch, 
1975), Cueva Soterraña (Sarrión, 1982), Cueva Merinel (Blay García, 1992), Loma de Betxí (Sarrión, 1998; Tormo Cuñat \& de Pedro Michó, 2013), Cueva II del Puntal del Horno Ciego, Cueva del Sapo, El Molar (Sarrión, 1990) and Cova de les Cendres (Iborra Eres \& Martínez del Valle, 2009). In most of these studies turtles are the only taxon mentioned (Bisbal-Chinesta \& Blain, 2018).

Here, we present the results of a study involving mainly the small-vertebrate remains from an approximately 1.3 m-thick, stratified, gravelly deposit at El Salt archaeological site (Alcoi, Alicante) ascribed to the Holocene (Fumanal, 1994). We have two main aims: 1) to characterise the small-vertebrate assemblage recovered at this deposit; 2) to narrow down its chronological framework, which is currently undetermined.

\section{SITE BACKGROUND}

El Salt site is located in the municipality of Alcoi (Alicante, southeastern Iberia, Spain), at $680 \mathrm{~m}$ above sea level. Its $6.3 \mathrm{~m}$ thick stratified deposit rests against a $38 \mathrm{~m}$-high Palaeocene limestone wall, formed at a thrust fault and covered with tufa and travertine (Fig. 1). Since 1986, El Salt has been studied systematically from an interdisciplinary perspective, focusing on the highresolution studies of Neanderthal behaviour (Mallol et al., 2013; Galván et al., 2014; Garralda et al., 2014; Sistiaga et al., 2014; Rodríguez-Cintas \& Cabanes, 2015; Machado \& Pérez, 2016; Molina, 2016; Vidal-Matutano, 2016; Pérez et al., 2017; Marquina-Blasco et al., 2017; Fagoaga et al., 2018; Vidal-Matutano et al., 2018; Leierer et al., 2019).
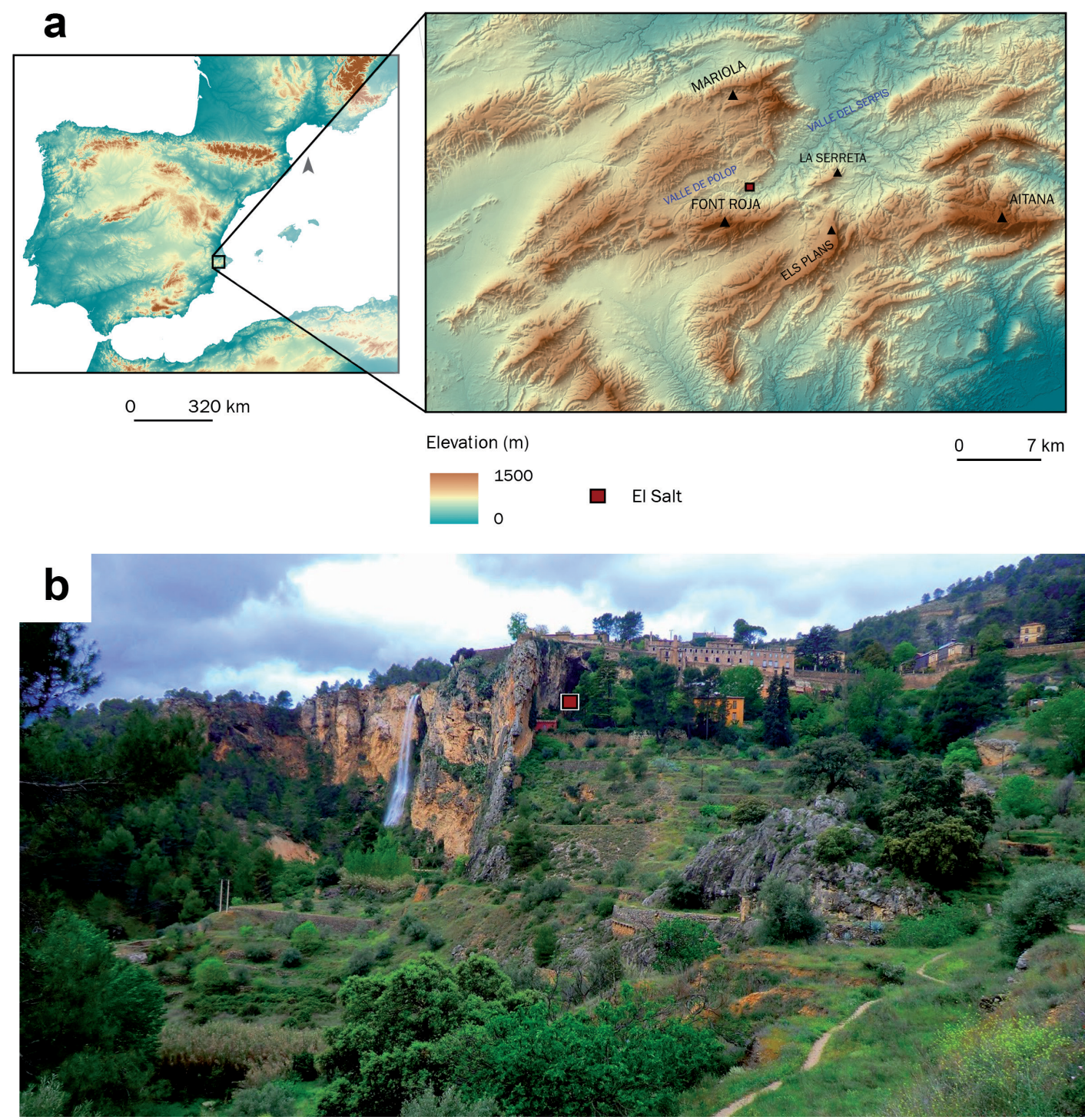

Figure 1. a) Geographic location of El Salt site in the Iberian Peninsula and its position in the Serpis Valley between Font Roja and Serra de Mariola mountain ranges. b) Panoramic view of El Salt (photography of Juan José Dopazo Javier). 
The sedimentary sequence comprises thirteen lithostratigraphic units (from XIII to I) described by Fumanal (1994) (Galván et al., 2014) (Fig. 2a). Pleistocene deposit ranges from Unit XIII to V. From bottom to top, Unit XIII consists on an archaeologically sterile subhorizontal travertine platform. In contrast, Units XII to IX contain the highest concentration of archaeological remains and combustion structures. These units are 1.5 $\mathrm{m}$-thick and are mainly constituted by horizontally bedded fine sand. From Unit VIII to the middle of Unit V there is considerably spatially reduced evidence of human input and progressively more non-archaeological sedimentation (Galván et al., 2014). Six upper teeth of possibly a Neanderthal juvenile or young adult were recovered at the base of Unit V (Garralda et al., 2014). The upper part of Unit V is archaeologically sterile except for its top part, where two small flint blades, a few undifferentiated flakes and a small combustion structure were recovered at the top of the unit (Garralda et al., 2014). The top of Unit V, is 50 $\mathrm{cm}$-thick, truncated, massive sandy silt with heterogeneous gravel in the top $20 \mathrm{~cm}$. Preliminary results from a smallmammal study showed a reduction in species diversity in Unit V compared with all of the underlying units (Fagoaga et al., 2018, 2019).

Units IV to I, the gravelly deposit described by Fumanal (1994) and ascribed to the Holocene based on the presence of Neolithic pottery, with a $1.3 \mathrm{~m}$ thick stratigraphic segment, comprise a stratified succession of channels filled with different beds of gravelly sands containing cobbles, separated by sharp erosional contacts. Unit IV, at the base, with a sandy matrix and 8-10 $\mathrm{cm}$-sized, subrounded and rounded pebbles and cobbles rests unconformably on the Pleistocene fine-grained deposit. Unit III contains smaller-sized gravel. Unit II is more poorly sorted than IV and III. Unit I is similar to the underlying unit but is slightly cemented. Neolithic pottery mixed with late Upper Palaeolithic, Epipalaeolithic and Mesolithic lithic remains indicates that this deposit is of Holocene age (Galván et al., 2014).

\section{MATERIAL AND METHODS}

The small-vertebrate fossil remains used for this study consist mainly of isolated teeth and bone fragments collected from El Salt Profile 13 during the 2015 field season. The study includes Unit I to IV from El Salt site (Alcoi, Alicante). From these Units, facies A, B, C, D and $\mathrm{E}$ have been studied. Giving the evidences of mixed materials ascribed to different chronological periods we have considered the different facies as belonging to the

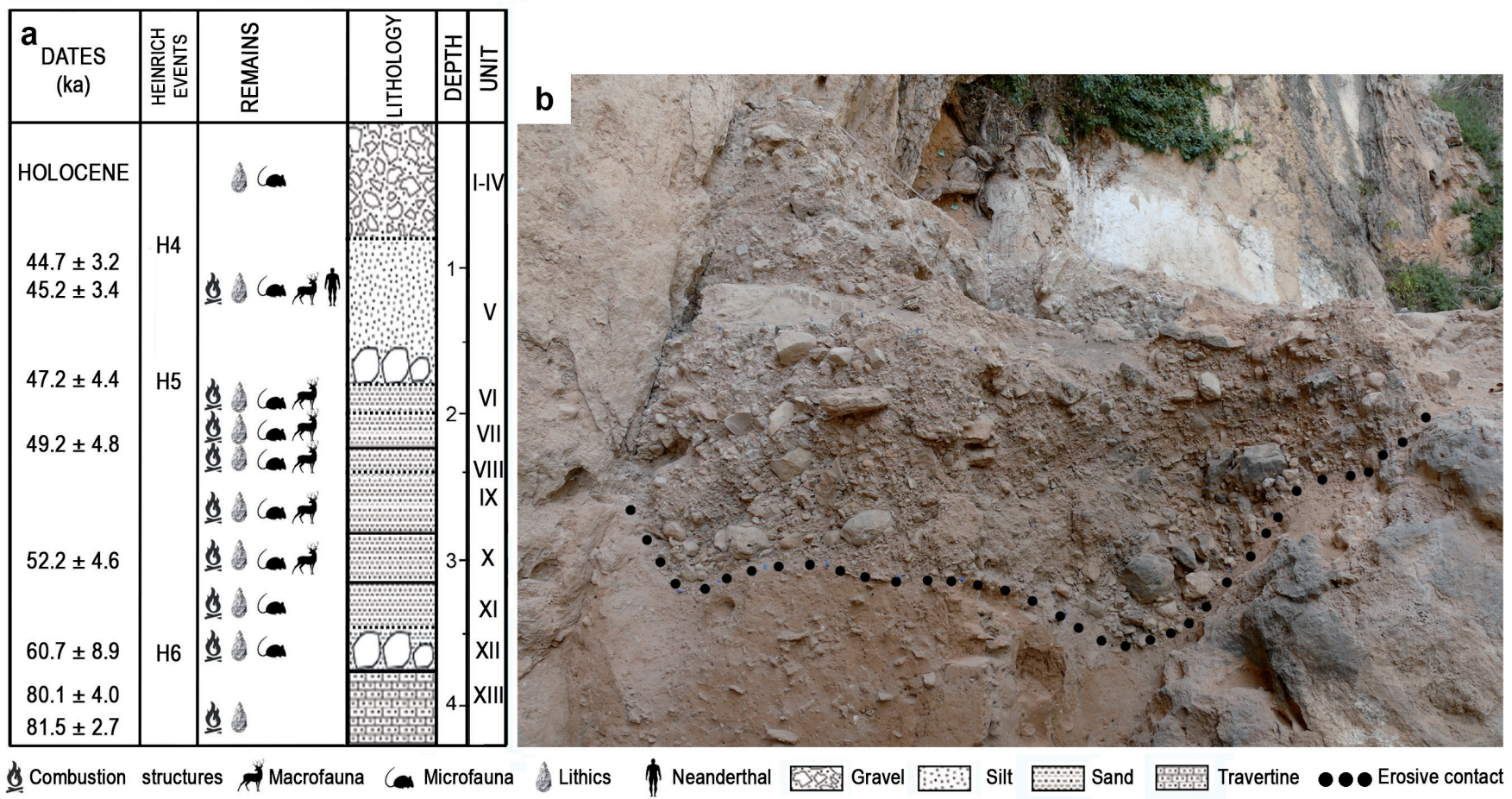

Figure 2. a) Stratigraphic log showing lithology, grain size, archaeological content (human remains, lithics, vertebrates and combustion structures), and small vertebrates, average chronometric dates and Heinrich Events (modified from Galván et al., 2014). b) Detail of the gravelly deposit (profile 13, $1.5 \mathrm{~m}$ width) from El Salt separated by an erosive contact indicated with black dots from the underlying Pleistocene deposit. 
same analytical unit. The fossil remains were obtained from the sediment by water sieving using a $0.5 \mathrm{~mm}$ mesh. The fossils were processed, sorted and classified using a Leica MS5 binocular microscope. Measurements were taken on a Leica MZ75 binocular microscope, by means of displacement of a mechanical stage connected to Sony Magnescale measuring equipment. Photographs were taken with a scanning electron microscope at The Central Support Facility for Experimental Research (SCSIE) of the Universitat de València. Malacofauna remains were classified at the Museu Valencià d'Història Natural de Alginet (Valencia, Spain).

Fossils were described and measured following the anatomical nomenclature and measurements methods given by van der Meulen (1973), Rabeder (1981), and Jeannet (2000) for arvicolines, van der Weerd (1976) for murids, Daams (1981) and Freudenthal (2004) for glirids, and, finally, Reumer (1984) for soricids. The taxonomic classification follows the one given by Wilson et al. (2016, 2017) and Wilson \& Mittemeier (2018). Within arvicolines, subgeneric classification follows Jaarola et al. (2004). In the case of the herpetological remains, bones were assigned to different taxa following the criteria given by Bailon (1991, 1999) and Blain (2009) for amphibian remains and Oelrich (1956), Szyndlar (1984), Barbadillo (1989), Bailon (1991), Barahona (1996), Barahona \& Barbadillo (1997), and Blain (2009) for Squamata. Comparisons were drawn using the collections of dry skeletons of the Museo Nacional de Ciencias Naturales (CSIC, Madrid, Spain), Muséum national d'Histoire naturelle (Paris, France), Gabinete de Fauna Cuaternaria of the Museu de Prehistòria de València (Valencia, Spain) and Departament de Botànica i Geologia from the Universitat de València (Burjassot, Spain). The morphologic nomenclature basically follows Oelrich (1956), Roček (1984), Szyndlar (1984), and Bailon (1991, 1999). We follow the taxonomic nomenclature of Uetz \& Hošek (2015) for reptiles and Frost (2015) for amphibians. All the measurements have been taken following Barahona \& Barbadillo (1997) for lacertids and Auffenberg (1967) and Blain (2009) for snakes.

Concerning post-depositional processes that affected the sample, comparative data for the different possible features were consulted on Andrews (1990), FernándezJalvo \& Andrews (1992, 2016), among others.

The material studied in the present work is temporally stored in the Departament de Botànica i Geologia of the Universitat de València (Burjassot, Spain), until their definitively storage in the Museu Arqueològic Municipal Camil Visedo Moltó (Alcoi, Spain). The fossils have been stored with the acronym ST-G followed by the facies (A, $\mathrm{B}, \mathrm{C}, \mathrm{D}$ and $\mathrm{E}$ ) and the collection number. Regarding to herpetofauna, the acronym may refer to more than one piece of the same type of bone in some specific cases (e.g., dorsal vertebrae).
The abbreviations used in this work are: c1, posterior accessory cusp; CL, vertebral centrum length; CL/NAW: relation between the length and the width of the vertebral centrum; CNW/CL, relation between the width of the condilar neck and the length of the vertebral centrum; $\mathrm{CNW} / \mathrm{NAW}$, relation between the width of the condilar neck and the width of the vertebral centrum; PO-PO/NAW, relation between the width of the external borders of the articular surfaces of the postzygapophysis and the width of the vertebral centrum; PR-PR/NAW, relation between the width of the external borders of the articular surfaces of the prezygapophysis and the width of the vertebral centrum; D4, fourth deciduous upper premolar; I, Upper incisor; i, lower incisor; $\mathrm{m} 1$, first lower molar; $\mathrm{m} 2$, second lower molar; m3, third lower molar; M1, first upper molar; M2, second upper molar; M3, third upper molar; Md, mandible; Mx, Maxilla; P2, second upper premolar; p3, third lower premolar; $\mathrm{p} 4$, forth lower premolar; tma, antero-central cusp; t1, t1bis, t2bis, t3, t4, t5, t6, t8, t9, tubercules 1 , 1bis, 3, 4, 5, 6, 8 and 9 respectively (genus Apodemus); T1, T2, T3, T4, T5, T6 and T7, triangles 1, 2, 3, 4, 5, 6 and 7 (genus Arvicola and Microtus).

\section{SYSTEMATIC PALAEONTOLOGY}

\author{
Phylum CHORDATA Bateson, 1885 \\ Class AMPHIBIA Linnaeus, 1758 \\ Order ANURA Duméril, 1806
}

Family Bufonidae Gray, 1825

Genus Epidalea Cope, 1864

Epidalea calamita (Laurenti, 1768)

Material. 3 dorsal vertebrae (ST-GB-108, ST-GC-103, ST-GE-35); 1 sacral vertebra (ST-GC-104); 1 humerus (STGB-112); 1 radioulna (ST-GB-107).

\section{Description.}

Vertebra. Vertebras are procoelus and wider than long. In dorsal view, the neural arch is short and bears a welldefined neural crest which runs along all its length. The prezygapophysis are large and project posterolaterally. A pair of lateral transverse is present in the neural arch, whose projection and shape depend to the position in vertebral column (Bailon, 1999). Thus, ST-GB-108 shows its transverse process projected forwards, as in second vertebra in Anurans. For their part, the tranverse process of ST-GC-103 and ST-GE-35 are narrow and less developed that those described above, typical traits of posterior 
vertebrae. In frontal and posterior view cotyle and condyle are dorso-ventrally flattened. The walls of the neural canal are wide and short.

In anurans, sacral vertebra is characterized by the presence of well-defined tranverse processes, which its articulate with the anterior border of the ilia (Bailon, 1999). ST-GC-104 is procoelous and wider than long. The remain has one anterior cotyle and two posterior condyles slightly dorso-ventrally compressed. In dorsal view, tranverse processes are broken but it is appreciable that are wide and moderately antero-posteriorly spread. A laterally and posteriorly opened dorsal fossa is present at the base of the processes. Neural arch bears a neural crest. In posterior view, condyles are in contact, partially fused at the medial region.

Humerus. The humerus has a diaphysis that is slightly curve in ventral view and without a paraventral crest. The ventral crest is well developed. The condyle is located slightly moved outwardly relative to the diaphyseal axis. The fossa cubitalis is well developed and close. Epicondyles are relatively well developed, being the ulnar epicondyler more develop than the radial one. The diaphysis is strong. ST-GB-112 shows neither mesial crest nor radial crest. Given the absence of medial crest it is possible that ST-GB-112 belonged to a female individual (Fig. 3a).

Radioulna. The radioulna has a proximal extreme (olecrane) is concave, drawing an angle over $135^{\circ}$. Foramen nutritium is large and well developed.

Femur. The femur is a long bone with a sigmoidal shape. The femoral crest is long, well defined and it is not divided.

Remarks. The specific determination of the different European toad species is mainly based in the morphology of postcranial elements (Blain, 2009). Thus, the above described traits of the sacral vertebra and the humerus (Fig. 3a) are consistent with a taxonomical attribution of Epidalea calamita (Bailon, 1999). The presence of an opened dorsal fossa in the base of the transverse processes allow us to discard this remains as Bufo spinosus Daudin, 1803, the other Iberian species of toad, in which the dorsal fossa is closed (Bailon, 1999). In addition, the dorsal fossa is opened both laterally and posteriorly which rules out the attribution of the remains to Bufotes viridis (Laurenti, 1768), a species of bufonid also present in Europe (Bailon, 1999). The humerus has its diaphysis well curved without paraventral crest and presents a closed fossa cubitalis and defined epicondyles as is observable in the comparation material of E. calamita. In contrast, the humerus' diapophysis is straight, more gracile and presents its distal region less developed in B. spinosus than in $E$. calamita (Bailon, 1999; Blain, 2009).
Class REPTILIA McCartney, 1802

Order SQUAMATA Oppel, 1811

Suborder Lacertilia Owen, 1842

Family Scincidae Oppel, 1811

Genus Chalcides Laurenti, 1768

Chalcides cf. bedriagai (Boscá, 1880)

Material. 2 premaxillae (ST-GB-104, ST-GE-36); 1 quadrate (ST-GE-37); 4 dentaries (ST-GA-142, 143, STGB-101, 102); 3 dental bones (ST-GA-154, ST-GB-103); 14 vertebral centra (ST-GA-149, 150, ST-GB-105, STGC-101, ST-GE-31, 32, 33, 34).

\section{Description.}

Premaxilla. In Scincidae premaxilla are unfused paired bones (Villa \& Delfino, 2019). Premaxillae have three dental positions. Teeth are pleurodont, cylindrical and monocuspid with the apex blunt. The nasal process is arrow-shape. In its base, it is present a pair of foramina. The premaxilla shelf is straight.

Quadrate. The quadrate is small-sized (L: $2.59 \mathrm{~mm}$ ). In anterior view, it is convex and subrectangular shape. The anterior platform (medial crest in Oelrich (1956)) has its first half broken. It is only present the anteromedial overture of the quadrate foramen. The pterygoid process is absent. In posterior view, the bone is curve, concave and wide. The cephalic condyle is large, straight and laterally expanded. The posterior crest is well developed, curve and occupies almost the entire length of the bone. The mandibular condyle is divided in two parts, a medial and a lateral, separated by a well marked posterolateral sulcus. Both parts show similar size (Fig. 3b).

Dentary. The teeth of the dentaries are pleurodont, isodont and unicuspids with a blunt apex. Some of them show in their apex a more or less visible ornamentation, with delicate vertical striation limited ventrally by a transverse groove. In lingual view, the Meckelian groove is open. The coronoid process is wide and short. The ventral end of the dentary is straight. In labial view, dentary does not show the impression of the coronoid in its posterior region. The most complete dentary, ST-GB-101, has 13 dental positions with 9 teeth present. These teeth show a relation width/high equal to 0.3 (Fig. $3 \mathrm{c}$ ).

Vertebral centrum. Centra are elongated and transversally concave. In ventral view, the remains have a pair of subcentral foramina. The cotyle and the condyle are dorsoventrally flattened in anterior and posterior view, respectively. Haemal crest is not present. 
Remarks. The presence of centrum with cotyle and condyle dorsoventrally flattened is a typical trait of Scincidae (Bailon, 1991). Quadrate shows typical traits of Scincidae (pterygoid process is absent, both parts of the mandibular condyle present similar size and cephalic condyle is not expanded posteroventrally (Villa \& Delfino, 2019). The presence of an unfused premaxilla and the overall morphology of the dentary (ventral end straight

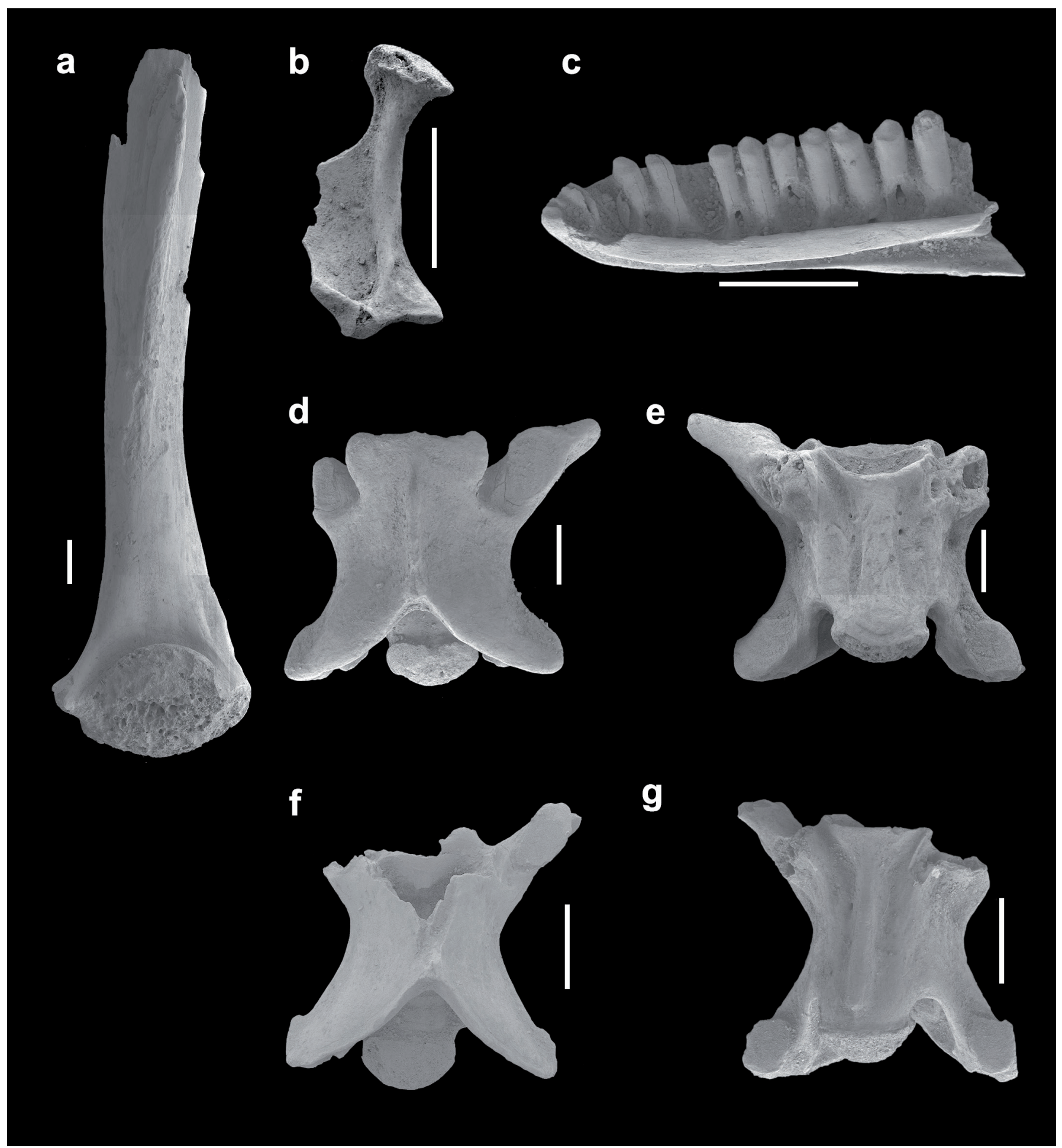

Figure 3. Herpetological remains recovered from the gravelly deposits from El Salt (Alcoi, Spain). a) ST-GB-112, left humerus, ventral view, Epidalea calamita. b) ST-GE-37, left quadrate, medial view, Chalcides cf. bedriagai. c) ST-GB-101, right dentary, lingual view, Chalcides cf. bedriagai. d) ST-GA-155, dorsal and e) ventral view, trunk vertebrae, Coronella cf. girondica. f) ST-GB-109, dorsal and g) ventral view, trunk vertebrae, cf. Coronella sp. Scale bar equal $1 \mathrm{~mm}$. 
and the absence of bi- or tricuspid teeth) are consistent with the genus Chalcides (Barbadillo, 1989; Bailon, 1991; Blain, 2009). The morphology and width/high proportion (0.3) of the teeth is similar to those of the modern species Chalcides bedriagai (Barbadillo, 1989). The absence of a complete dentary does not allow us to ascribe these remains to the species with safely; since one of the criteria used for the specific level of ascription in the Iberian species of the genus Chalcides is the number of teeth in the tooth. In the case of $C$. bedriagai, it shows 15 to 18 dental positions (Caputo, 2004).

Family Lacertidae Oppel, 1811

Lacertidae indet. "Small-sized lacertid"

Material. 1 premaxilla (ST-GA-144); 4 maxillae (STGA-151, ST-GA-152); 2 dental bones (ST-GB-110); 2 femurs (ST-GA-145, ST-GA-146); 1 cervical vertebra (ST-GB-113); 3 dorsal vertebrae (ST-GA-147, ST-GB-106, ST-GC-102).

\section{Description.}

Premaxilla. ST-GA-144 is a very fragmentary premaxilla, consisting of only in the premaxilla shelf. This element is an unpaired bone which is the result of the fussion of both premaxillae during early embrionic stages (Barahona, 1996). Only 3 teeth of 7 dental positions are preserved. They are pleurodont, isodont, cylindrical and monocuspid, with blunt apex. At the base of the broken nasal process, it is present a large foramen. In lingual view, the incisive process is big and rounded.

Maxilla. Maxilla shows a poor state of conservation. The unique preserved process is the zygomatic process, which is straight, low and short, with blunt apex. Teeth are pleurodont, isodont and mono or binocuspid, being the central cuspid more developed than the lateral one.

Vertebra. Vertebra is procoelus, longer than wider. In dorsal view, the neural spine occupies all the neural arch, not finishing in a point that overtakes the posterior end of the postzygapophysis, trait that distinguishes Lacertidae to Scincidae (Bailon, 1991). Interzygapophyseal constriction is little marked, which differs from Scincidae (Bailon, 1991). Prezygapophysis projects upward, unfortunately postzygapophysis are broken. In ventral view, centrum has a convex surface and triangular-shape and shows a pair of foramens well defined. ST-GB-113 is wider than long. In ventral view, the centrum has a broken hypapophysis. Both traits denotes that ST-GB-113 is a cervical vertebra (Hoffstetter \& Gasc, 1969; Bailon, 1991).

Femur. Two proximal ends of femora, one right and one left, have been recovered from El Salt site. Epiphyses are wider than the diaphyses. In ventral view, the femoral condyle is large and oval shape. The internal trochanter is smaller than the anterior, antero-laterally expanded, intertrochanteric fossa. Both elements are separated by a deep intertrochanteric fossa.

Remarks. The remains from El Salt show typical traits of Lacertidae: teeth pleurodont, isodonts and mono, bi or tricuspids, premaxilae fused and procoele vertebra with centrum convexe and neural spine not exceeding the posterior limit of the postzygapophysis (Bailon, 1991). However, the studied material shows a poor preservation state. Thus, it is impossible to establish a more precise taxonomical attribution. On the other part, the small sized of the remains allow us to reject the large European lacertids genera, as Timon Tschudi, 1836, and Lacerta Linnaeus, 1758.

\section{Suborder Serpentes Linnaeus, 1758}

$$
\text { Serpentes indet. }
$$

Material. 3 centra (ST-GA-148, ST-GB-111).

\section{Description.}

Centrum. Centrum are triangular-shape and longer than wide, give it an elongated appearance. In ventral view, centrums show a pair of small foramens. Two morphologies can be distinguished. ST-GA-148 contains the biggest centra (LC: $5.76 ; \mathrm{n}: 2 ; \sigma: 0.84$ ). It shows a welldefined haemal keel that finish in a broken hypapophysis. The latest structure is connected with the condyle. The second centrum (LC: $3.92 \mathrm{~mm}$; $\mathrm{n}$ : 1) shows a haemal keel with diffuse margins in its final quarter. In these remains, the condyle is large and rounded in posterior view.

Remarks. The described centrum shows the typical morphology attributed to snake vertebra: triangular-shape and rounded condyle (Bailon, 1991). These remains are highly fragmentary, for this reason it is impossible to propose a more concrete taxonomical attribution.

Family Colubridae Oppel, 1811

Genus Coronella Laurenti, 1768

Coronella cf. girondica (Daudin, 1803)

Material. 1 vertebra (ST-GA-155).

Description. The vertebra is small (LC: $3.08 \mathrm{~mm}$; $\mathrm{n}: 1$ ), procoelus and slightly longer than wider (CL/NAW: 0.81). The interzygapophyseal constriction is well developed. In 
dorsal view, the prezygapophysis and postzygapophysis are distinct from the neural arch. The prezygapophyseal process is straight, well developed and projects laterally. The prezygapophysial processes are short and finished rounded. The articular surfaces of the prezygapophysis are large and oval-shape. The zygosphene is trilobulate with the two lateral ones bigger than the central. The neural spine runs along the entire length of the neural arch, except of its anterior first third (Fig. 3d). In lateral view, neural spine is low. Diapophysis and parapophysis are broken, however it is possible to appreciate that both are of similar size. A large lateral foramen is present. The margolateralis is diffuse. In ventral view, the centrum is triangular shape. It is wider anteriorly than posteriorly and not well-defined lateral margins. A pair of small paracotilar foramens is present. The centrum has a wide haemal keel with lateral margins well defined, except in its final third (Fig. 3e). In frontal and posterior view, the neural arch is dorso-ventrally flattened. Cotyle and condyle are big and rounded.

Remarks. The presence of a well marked precondilar constriction, strongly depressed neural arch and short prezygapophyseal processes are characteristic of the genus Coronella that differs from other ophidian species of Iberian Peninsula (Szyndlar, 1984; Bailon, 1991; Blain, 2009). Morphologically C. girondica and C. austriaca Laurenti, 1768 differ in that the latter has prezygapophyseal processes that are less wide at the base and longer and the size of parapophyses in relation to the diapophyses is larger in C. austriaca than in C. girondica (Szyndlar, 1984; Bailon, 1991). In this sense, ST-GA-155 presents traits similar to current osteological material of $C$. girondica. However, these characters may show a certain degree of variation, for this reason the species attribution is made with caution (Blain et al., 2011). For this reason, we propose a taxonomical attribution of the remains at generic level.

\section{cf. Coronella sp.}

Material. 1 vertebra (ST-GB-109).

Description. The specimen labelled ST-GB-109 is a procoelus vertebra, small sized (LC: $2.82 \mathrm{~mm} ; \mathrm{n}: 1$ ) and longer than wide. In dorsal view, it shows a well marked interzygapophyseal constriction. The anterior half of the neural arch is partially broken, for this reason some structures, as condyle, prezygapophyseal processes and neural spine, have disappeared. The articular surfaces of the prezygapophysis are large, elongated and ovalshaped. In lateral view, margolateralis are well defined as the margoventralis. Parapophysis is preserved, and it is large and rounded. On the other hand, the diapophysis is broken, but, even so, it is of a similar size to the previous one. Close to the base of the prezygapophyseal process is located the lateral foramen on the bottom of a small depression (Fig. 3f). In ventral view, the centrum is convexe in tranverse section and is longer than wide. The base of the prezygapophyseal process is narrow. The haemal keel is narrow and well-defined margins in full of its length (Fig. 3g). In spite of the poor state of conservation of the neural arch, it seems to be dorsoventrally flattened. The contyle and the condyle are sub-circular shape in anterior and posterior view, respectively. In this latter view, the upper border of the neural arch is slightly convexe. The haemal keel finishes in a small protuberance.

Remarks. ST-GB-109 presents the typical traits of genus Coronella (small size, well marked precondilar constriction, strongly depressed neural arch and short prezygapophyseal processes). However, the presence of a straight haemal keel with lateral margins well defined is not reported from that genus, but present in Hemorrhois hippocrepis (Linnaeus, 1758) (Bailon, 2000). On the other hand, applying the biometrical method for the determination of the trunk vertebrae of "colubrids" snake (trunk vertebrae without hypapophysis) stablished by Blain (2009), ST-GB-109 shows disparate measures. For example, CNW/CL is compatible with Coronella girondica, however the rest of biometrical measurements (CNW/NAW, CL/NAW, PR-PR/NAW and PO-PO/NAW) are inconsistent with this taxonomical attribution. For this reason, we prefer to propose an open generic attribution based only on morphological traits.

Class MAMMALIA Linnaeus, 1758

Order EULIPOTYPHLA Waddell et al., 1999

Family Soricidae Fischer, 1817

Genus Sorex Linnaeus, 1758

Sorex sp.

Material. 1 M1 (ST-GB-9); 1 M3 (ST-GB-34) (Tab. 1).

\section{Description.}

M1. Tooth with low crown (brachydont). Secodont molar with reddish pigmentation restricted to the cusps of the tooth. The metaloph does not reach the hypocone. There is a well-developed hypoconal flange and a pronounced posterior emargination. The metacone is the highest cusp, and the paracone is higher than the protocone. The metacrest is the largest crest of the ectoloph, which is asymmetric.

M3. Brachydont. Secodont molar with a subtriangular outline. Reddish pigmentation restricted to the cusp of the 
paracone, which is the highest cusp. There is no anterior cingulum. The metacone is reduced to the paramesocrest.

Remarks. Only two teeth, first and third upper molars, with red-stained cusps are present in the studied sample. Soricids are represented in the Iberian Peninsula during Late Pleistocene and Holocene by two groups of species, the red-toothed shrews and the white-toothed shrews. From these, two genera of shrews (Neomys Kaup, 1829 and Sorex) with red-coloured teeth have been cited during that period. Usually, upper molars of the Neomys species are larger, have lower cusps and show a more reduced hypocone compared to Sorex representatives (Jammot, 1974). The dimensions of the molars from El Salt (Tab. 1), their relatively high cusps and the marked hypocone allow including them in the genus Sorex. The scarcity of material prevents a more precise identification.

\section{Subfamily Crocidurinae Milne-Edwards, 1874}

Genus Crocidura Wagler, 1832

\section{Crocidura sp.}

Material. 2 M1 (ST-GC-6, ST-GE-7); 1 Md (ST-GA45a); 1 p4 (ST-GB-12); $1 \mathrm{~m} 1$ (ST-GA-127); $1 \mathrm{~m} 2$ (ST-GA45b), $1 \mathrm{~m} 3$ (ST-GA-45c) (Tab. 1); (Fig. 4).

\section{Description.}

M1. Brachydont. Secodont molars. The metaloph does not reach the hypocone. There is a well-developed hypoconal flange and a pronounced posterior emargination. The mesostyle is continuous. The paracrest is the shortest crest in the ectoloph. The metastyle is long. The posterior cingulum is well developed and is presented between the metastyle and the posterior emargination. The metacone and the protocone are higher than the paracone. The ectoloph is very asymmetric. Not pigmented teeth.

p4. Brachydont. Secodont and non pigmented tooth. Tetrahedral shape without accessory cusps. Just one cusp, located in the anterior part of the tooth.

m1. Brachydont. Secodont and non pigmented tooth. Short talonids. The oblique crest does not reach the posterior surface of the trigonid by its central part, it reaches in a more labial position. The crest of the entoconid connects with the metaconid. Not pronounced entostylid.

$\underline{\mathrm{m} 2}$. Brachydont. Secodont and non pigmented tooth. Short talonids. The oblique crest does not reach the posterior surface of the trigonid by its central part, it reaches in a more labial position. The crest of the entoconid connects with the metaconid. Not pronounced entostylid. It presents a very slightly constriction in the cingulum by its labial part.
Table 1. Measurements, in millimeter, of the teeth of micromammals at El Salt site (Unit IV-I). AW: anterior width; BL: buccal length; L: length; LL: lingual length; Min: Minimum value measured; Max: Maximum value measured; $N$ : number of specimens measured; PE: posterior emargination; PW: posterior width; SD: standard deviation; W: width.

\begin{tabular}{|c|c|c|c|c|c|c|}
\hline & $\mathbf{N}$ & Measure & Min. & Max. & Mean & SD \\
\hline \multicolumn{7}{|c|}{ Sorex sp. } \\
\hline \multirow{5}{*}{ M1-2 } & 1 & $\mathrm{BL}$ & & & 1.65 & \\
\hline & 1 & $\mathrm{PE}$ & & & 1.27 & \\
\hline & 1 & $\mathrm{LL}$ & & & 1.49 & \\
\hline & 1 & AW & & & 1.77 & \\
\hline & 1 & PW & & & 1.99 & \\
\hline \multirow{2}{*}{ M3 } & 1 & $\mathrm{~L}$ & & & 0.91 & \\
\hline & 1 & $\mathrm{~W}$ & & & 1.25 & \\
\hline \multicolumn{7}{|c|}{ Oryctolagus cuniculus } \\
\hline \multirow{2}{*}{ p3 } & 2 & $\mathrm{~L}$ & 2.59 & 3.13 & 2.86 & 0.38 \\
\hline & 2 & $\mathrm{~W}$ & 2.78 & 3.01 & 2.89 & 0.16 \\
\hline \multicolumn{7}{|c|}{ Arvicola sapidus } \\
\hline \multirow{2}{*}{$\mathrm{m} 2$} & 1 & $\mathrm{~L}$ & & & 2.57 & \\
\hline & 1 & W & & & 1.51 & \\
\hline \multirow{2}{*}{$\mathrm{m} 3$} & 1 & $\mathrm{~L}$ & & & 2.56 & \\
\hline & 1 & W & & & 1.27 & \\
\hline \multicolumn{7}{|c|}{ Microtus sp. } \\
\hline \multirow{2}{*}{ M1 } & 5 & $\mathrm{~L}$ & 1.84 & 2.38 & 2.10 & 0.20 \\
\hline & 4 & W & 0.85 & 1.13 & 1.04 & 0.13 \\
\hline \multirow{2}{*}{ M2 } & 3 & $\mathrm{~L}$ & 1.67 & 1.82 & 1.77 & 0.09 \\
\hline & 3 & W & 1.03 & 1.11 & 1.08 & 0.04 \\
\hline \multicolumn{7}{|c|}{ Microtus arvalis } \\
\hline \multirow{2}{*}{ M3 } & 1 & $\mathrm{~L}$ & & & 2.06 & \\
\hline & 2 & $\mathrm{~W}$ & 0.98 & 1 & 0.99 & 0.02 \\
\hline \multirow{2}{*}{$\mathrm{m} 1$} & 2 & $\mathrm{~L}$ & 2.89 & 3.21 & 3.05 & 0.22 \\
\hline & 2 & W & 0.97 & 1.14 & 1.06 & 0.12 \\
\hline \multirow{2}{*}{$\mathrm{m} 2$} & 6 & $\mathrm{~L}$ & 1.48 & 1.67 & 1.56 & 0.07 \\
\hline & 6 & W & 0.76 & 0.99 & 0.92 & 0.09 \\
\hline \multirow{2}{*}{$\mathrm{m} 3$} & 3 & $\mathrm{~L}$ & 1.3 & 1.73 & 1.45 & 0.12 \\
\hline & 3 & $\mathrm{~W}$ & 0.72 & 0.94 & 0.80 & 0.12 \\
\hline Micro & & & & & & \\
\hline M2 & 1 & $\mathrm{~L}$ & & & 1.67 & \\
\hline $\mathrm{I} 12$ & 1 & W & & & 1.22 & \\
\hline Micro & itus & & & & & \\
\hline M2 & 1 & $\mathrm{~L}$ & & & 1.66 & \\
\hline M2 & 1 & $\mathrm{~W}$ & & & 0.99 & \\
\hline M3 & 2 & $\mathrm{~L}$ & 1.64 & 1.86 & 1.75 & 0.15 \\
\hline & 2 & W & 0.84 & 0.97 & 0.90 & 0.09 \\
\hline$m 2$ & 2 & $\mathrm{~L}$ & 1.5 & 1.61 & 1.55 & 0.08 \\
\hline $\mathrm{m} 2$ & 2 & W & 0.8 & 0.81 & 0.80 & 0.00 \\
\hline $\mathrm{m}^{3}$ & 3 & $\mathrm{~L}$ & 1.3 & 1.43 & 1.38 & 0.07 \\
\hline m3 & 2 & W & 0.71 & 0.82 & 0.76 & 0.08 \\
\hline Apode & & & & & & \\
\hline M1 & 2 & $\mathrm{~L}$ & 1.83 & 2.06 & 1.95 & 0.16 \\
\hline MI & 2 & W & 1.27 & 1.32 & 1.29 & 0.03 \\
\hline M? & 2 & $\mathrm{~L}$ & 1.25 & 1.29 & 1.27 & 0.03 \\
\hline M2 & 1 & W & & & 1.16 & \\
\hline $\mathrm{M3}$ & 1 & $\mathrm{~L}$ & & & 1.05 & \\
\hline M13 & 1 & W & & & 0.97 & \\
\hline & 4 & $\mathrm{~L}$ & 1.77 & 1.89 & 1.84 & 0.06 \\
\hline $\mathrm{ml}$ & 5 & W & 1.06 & 1.16 & 1.13 & 0.04 \\
\hline & 3 & $\mathrm{~L}$ & 1.24 & 1.25 & 1.25 & 0.01 \\
\hline $\mathrm{m} 2$ & 4 & $\mathrm{~W}$ & 1.12 & 1.24 & 1.16 & 0.06 \\
\hline Eliom & & & & & & \\
\hline P4 & 1 & $\mathrm{~L}$ & & & 1.06 & \\
\hline & 1 & W & & & 1.64 & \\
\hline d4 & 1 & $\mathrm{~L}$ & & & 1.23 & \\
\hline d4 & 1 & W & & & 1.14 & \\
\hline
\end{tabular}


$\underline{m 3}$. Brachydont. Secodont and non pigmented tooth. Subrectangular outline. The talonid, which is narrower than the trigonid, is reduced to small crest with a tiny depression. The protonocid is the highest cusp. Small buccal cingulum compared to the anterior one.
Remarks. The remains identified are characterised by the absence of pigmentation and the upper molars are extended labio-lingually, which are typical features of the genus Crocidura (Furió, 2007). This is the only shrews' genus with unpigmented teeth during the Late
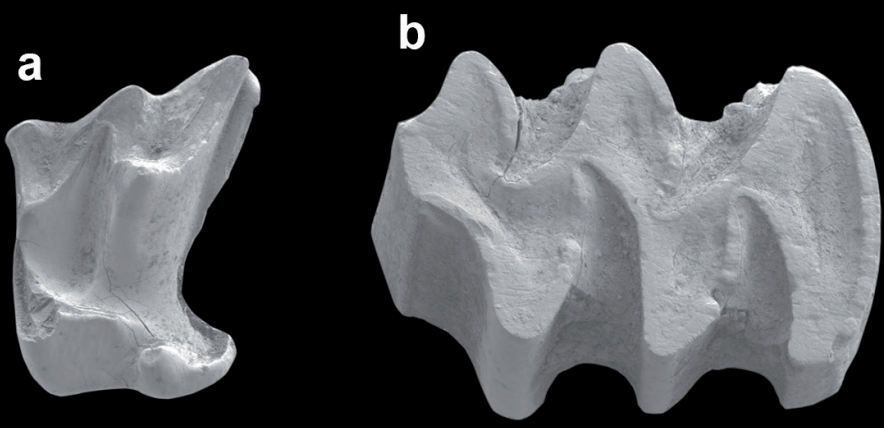

C

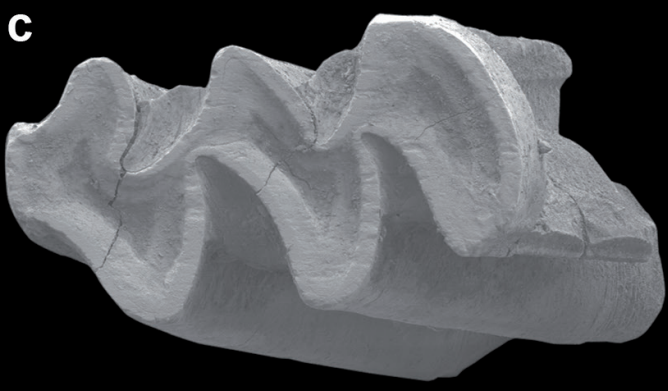

d
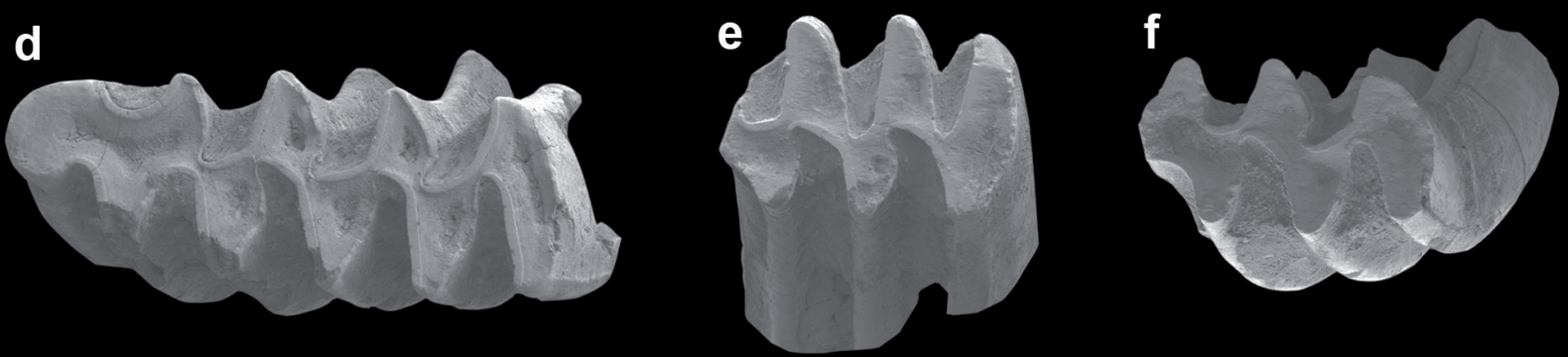

g

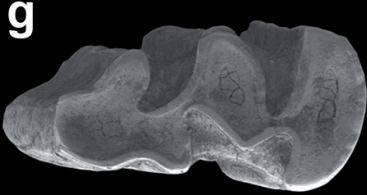

h

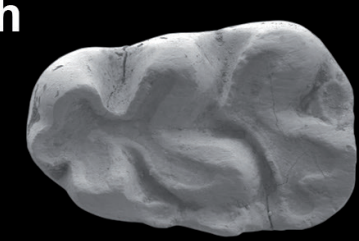

i

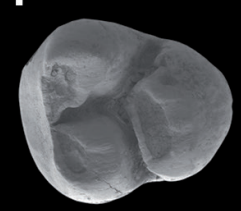

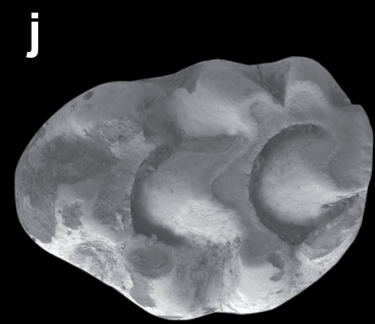

$\mathbf{k}$

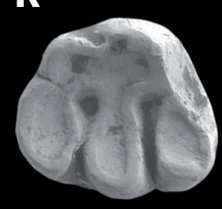

I

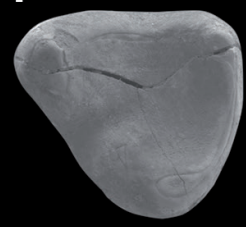

Figure 4. Some of the small mammal remains recovered from the gravelly deposit from El Salt (Alcoi, Spain). a) ST-GE-27, left M1, Crocidura sp. b) ST-GA-37, right m2, Arvicola sapidus. c) ST-GA-34, right m3, Arvicola sapidus. d) ST-GC-53, right m1, Microtus arvalis. e) ST-GC-10, left m2, Microtus arvalis. f) ST-GE-3, right m2, Microtus duodecimcostatus. g) ST-GB-17, left M3, Microtus duodecimcostatus. h) ST-GA-10, left m1, Apodemus sylvaticus. i) ST-GA-16, right m3, Apodemus sylvaticus. j) ST-GA-5, left M1, Apodemus sylvaticus. k) ST-GC-5, right M3, Apodemus sylvaticus. l) ST-GD-6, left p4, Eliomys quercinus. Scale bar equal 1 mm. 
Pleistocene and most of the Holocene of the Iberian Peninsula, with two species, C. russula (Hermann, 1780) and C. gueldenstaedtii (Pallas, 1811), recorded at this time interval. The presence of a slightly constriction in the cingulum is not enough to ascribe the remains to the species level. In the absence of an upper fourth premolar, from which the determinations are based (Poitevin et al., 1986), that material is identified as Crocidura sp.

\section{Order LAGOMORPHA Brandt, 1855}

Family Leporidae Fischer, 1817

Genus Oryctolagus Linnaeus, 1758

Oryctolagus cuniculus Linnaeus, 1758

Material. $1 \mathrm{Mx}$ (ST-GD-32a); 19 I (ST-GA-72 to ST-GA-76, ST-GA-103 to ST-GA-105, ST-GA-107, STGC-29 to ST-GC-32, ST-GC-46, ST-GC-100, ST-GD-11, ST-GD-12, ST-GD-18, ST-GD-22 ); 2 P2 (ST-GA-95, STGC-45); 48 Upper Molariforms (ST-GA-79; ST-GA-81 to ST-GA-87, ST-GA-96 to ST-GA-101, ST-GA-108, STGB-45, ST-GB-46, ST-GB-66 to ST-GB-68, ST-GB-48 to ST-GB-51, ST-GB-61, ST-GB-64, ST-GB-66, ST-GB-77 to ST-GB-79, ST-GC-36 to ST-GC-43, ST-GC-82 to STGC-85, ST-GC-96 to ST-GC-98, ST-GD-12, ST-GD-14, ST-GD-19, ST-GD-20); 1 Md (ST-GA-90); 9 i (STGA-77, ST-GA-89, ST-GA-102; ST-GA-106, ST-GB-47, ST-GB-48, ST-GC-33, ST-GC-34, ST-GC-95); 3 p3 (STGA-91, ST-GD-32, ST-GE-30); 6 Lower Molariforms (ST-GA-80, ST-GA-88, ST-GC-35, ST-GC-81, ST-GC-99; ST-GD-32c); 7 m3 (ST-GA-78, ST-GB-66, ST-GC-44, STGC-63, ST-GC-80, ST-GD-21; ST-GD-27) (Tab. 1).

\section{Description.}

I. Deep indentation on its labial surface, giving place to two lobes on either side of this longitudinal groove. The anterior lobes have a marked convexity and the mesial one is ledge and rounded.

p3. Hypsodont tooth. The lingual and vestibular anteroconids are very similar in size and shape, welldeveloped and rounded. The anteroflexid, with a vertical position, is quite deep. The paraflexid is slightly marked. The hipoflexid crosses the entire width of the tooth, with some crenulations.

Remarks. Upper incisors and third lower premolars are the diagnostic elements within the leporids (Callou, 1997). The $\mathrm{p} 3$ is the dental remain with a major morphological differentiation and is usually abundant in the fossil record (de Marfà, 2009). Both anteroconids are very similar, which is the typical morphology of Oryctolagus (Callou, 1997). On the contrary, lingual and vestibular anteroconids are dissymmetric in hares (Donard, 1982). The incisors show the deep indentation on its labial surface typical of the lagomorphs, and bear two rounded lobes similar in size and shape, which is also the morphology of Oryctolagus (Callou, 1997). Regarding biometry, the analysis that relates length versus weight shows that values fall within the values of modern Oryctolagus cuniculus (de Marfà, 2009) (Tab. 1; Fig. 5). Therefore, all those characters point us to identify the remains as belonging to $O$. cuniculus, besides the fact that $O$. cuniculus is the unique species of the genus during the Late Pleistocene and Holocene of the Iberian Peninsula (Pelletier, 2018).

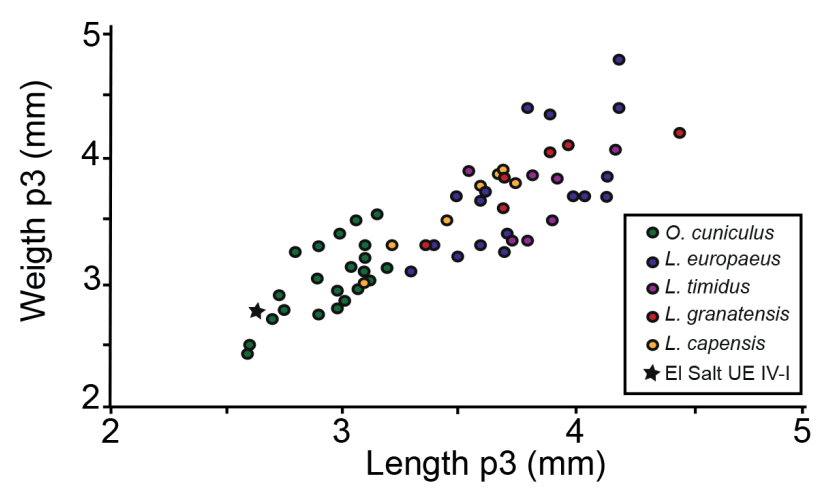

Figure 5. Biometric relation between length and weight of the third lower premolar (p3) in different species of current leporids (modified from De Marfà, 2009).

Order RODENTIA Bowdich, 1821

Family Cricetidae Gray, 1821

Genus Arvicola Lacépède, 1799

Arvicola sapidus Miller, 1908

Material. 1 M1-2 (ST-GC-62); $1 \mathrm{~m} 1$ (ST-GA-35); $1 \mathrm{~m} 2$ (ST-GA-37), 1 m3 (ST-GA-34) (Tab. 1; Fig. 4).

\section{Description.}

M1-2. The teeth are big, hypselodonts and with cement on the re-entrant triangles. The enamel is thicker on the anterior triangles.

$\underline{\mathrm{m} 1}$. The teeth are big, hypselodontsand with cement on the re-entrant triangles. They have a posterior loop, three closed triangles and an anterior complex formed by triangles $t 4$ and $t 5$ which are opposite, confluent and opened to an anterior loop. The enamel is thicker on the posterior triangles.

$\underline{\mathrm{m} 2}$. The teeth are big, hypselodonts and with cement on the re-entrant triangles. Tooth with four triangles and 
a posterior loop. The enamel is thicker on the posterior triangles. There is a big confluence between $\mathrm{t} 3-\mathrm{t} 4$.

$\underline{\mathrm{m} 3}$. The teeth are big, hypselodonts and with cement on the re-entrant triangles. Tooth with four triangles and a posterior loop. The enamel is thicker on the posterior triangles. There is a big confluence between $\mathrm{t} 1-\mathrm{t} 2$ and $\mathrm{t} 3-\mathrm{t} 4$.

Remarks. The genus Arvicola is characterized by the presence of five triangles in the $\mathrm{m} 1$ and the large size and the thick enamel of the molars. The thicker enamel in the anterior triangles in the upper molars and the thicker enamel in the posterior triangles in the lower molars led us ascribe the material to Arvicola sapidus (LópezMartínez, 1980). The other species of the genus Arvicola in the Late Pleistocene in the Iberian Peninsula, Arvicola monticola (de Sélys-Longchamps, 1839) presents the opposite pattern, being the enamel narrower in the anterior triangles in the upper molars and the posterior triangles in the lower molars (López-Martínez, 1980).

Genus Microtus Schrank, 1798

\section{Microtus sp.}

Material. 15 M1 (ST-GA-17 to ST-GA-19, ST-GA-128, ST-GA-129, ST-GB-13 to ST-GB-15, ST-GB-96, STGB-97, ST-GC-8, ST-GC-58, ST-GC-65, ST-GD-9, STGD-10); 11 M2 (ST-GA-20 to ST-GA-24, ST-GA-130, ST-GA-141, ST-GC-17, ST-GC-60, ST-GC-66, ST-GC-67); 1 M1-2 (ST-GC-19); 2 m1 (ST-GC-9, ST-GC-13); $1 \mathrm{~m} 2$ (ST-GD-11) (Tab. 1).

\section{Description.}

M1. The teeth are broken. They are hypselodonts. The triangles are rounded, closed and not confluent.

$\underline{\mathrm{m} 1}$. Hypselodont tooth without ACC (broken), high wear degree. Closed triangles.

Remarks. The specimens determined as Microtus sp. are very scarce and poorly preserved. However, the morphology described above and the size of the molars (Tab. 1) allows us to relate those remains to Microtus sp. In the absence of more diagnostic elements, we prefer to maintain this material under open nomenclature.

Subgenus Microtus Schrank, 1798

Microtus arvalis (Pallas, 1779)

Material. 9 M3 (ST-GA-32, ST-GB-16, ST-GB-30, ST-GB-31, ST-GB-99, ST-GB-100, ST-GC-61, ST-GC-68,
ST-GA-33), 11 m1 (ST-GA-26, ST-GA-27, ST-GA-30, STGA-92, ST-GA-136, ST-GC-71, ST-GC-72, ST-GC-94, STGD-8, ST-GD-31b); $11 \mathrm{~m} 2$ (ST-GA-29, ST-GA-138, STGB-19, ST-GC-10 to ST-GC-12, ST-GC-54, ST-GC-75, ST-GD-12, ST-GD-28, ST-GD-31c); 2 m1-m2 (ST-GC-15, ST-GC-18); 5 m3 (ST-GA-38, ST-GB-20, ST-GB-32, STGC-57, ST-GD-14) (Tab. 1; Fig. 4).

\section{Description.}

M3. Hypselodont teeth. It is composed by four lingual boucles and three labial boucles. It has three closed triangles that are not confluent with the posterior complex.

m1. Hypselodont teeth. The teeth have five closed triangles (T1 to T5), the buccal triangles reach a similar development than the labial ones, and the anterior complex has a symmetrical appearance, with T6 and T7 well developed.

m2. It has no roots. The teeth are hypsodont, with cement on the reentrant triangles. Composed by four triangles and a posterior loop. T3 and T4 are not confluent.

m3. It has no roots. The teeth are hypsodont, with cement on the reentrant triangles. Composed by four triangles and a posterior loop. T1-T2 and T3-T4 are confluent and the angles are not sharp. There is a big labiolingual asymmetry, the labial triangles are very narrow and small.

Remarks. The transverse symmetry of the molars, the parallel position of T4/T7 and T6/T7 and the rounded shape of the anteroconid complex are diagnostic features of $M$. arvalis (Cuenca-Bescós et al., 2008). Moreover, the weight between LRA5 and BRA4 fall within the values of this species $(\mathrm{d}>0.2 \mathrm{~mm})$. These features differ from the features belonging to $M$. agrestis, that includes more asymmetric disposition and stronger alternation of the reentrant angles, especially in T4-T5, a more reduced confluence between T6-T7 that implies a more angular ACC (Chaline, 1972; Luzi et al., 2017; Nadachowski, 1982).

Subgenus Iberomys Chaline, 1972

\section{Microtus cabrerae Thomas, 1906}

Material. 1 Mx (ST-GB-84a); 1 M1 (ST-GB-84b); 2 M2 (ST-GA-36, ST-GA-131); 1 M1-2 (ST-GA-135); 2 M3 (ST-GA-25, ST-GB-29); 1 m1 (ST-GB-85); $1 \mathrm{~m} 2$ (STGB-98); 1 m1-2 (ST-GB-86).

\section{Description.}

M1. The tooth is hypselodont. The reentrant angles have cement. Tooth with four triangles and an anterior loop. There is a big labio-lingual asymmetry and the triangles are acute. 
M2. The teeth are hypselodont. The reentrant angles have cement. Tooth with four triangles and an anterior loop. There is a big labio-lingual asymmetry and the triangles are acute.

M3. The teeth are hypselodont. The reentrant angles have cement. Tooth with four triangles and an anterior loop. There is a big labio-lingual asymmetry.

$\underline{\mathrm{m} 1}$. The teeth are broken, and hypseolodonts. The reentrant angles have cement. There is a big asymmetry of the ACC. LRA 3 and BRA 3 alternate. T4 and T5 are not confluent. The triangles are acute.

$\underline{\mathrm{m} 2}$. The teeth are hypselodonts. The reentrant angles have cement. Tooth with four triangles and a posterior loop. There is a big labio-lingual asymmetry, being the lingual salients markedly longer in a lateromedial direction and more acute than the labials.

Remarks. The marked anteroposterior compression of the molars, especially in $\mathrm{m} 1$, and the sharpness of the salient triangles are characteristic of the subgenus Iberomys (Chaline, 1972). Moreover, the molars assigned to Microtus cabrerae show abundant cement in the reentrant angles. The $\mathrm{m} 1$ has five closed triangles and an anterior lobe triangular in shape. The buccal triangles are shorter than the lingual ones, giving to the molar a moderately asymmetrical appearance. All these characters allow including the material of El Salt in the species $M$. cabrerae (Chaline, 1972; Ayarzagüena \& López-Martínez, 1976).

Subgenus Terricola Fatio, 1867

Microtus duodecimcostatus (de Sélys-Longchamps, 1839)

Material. 1 M2 (ST-GE-2); 4 M3 (ST-GA-31, STGB-17, ST-GC-16, ST-GC-70); 3 m1 (ST-GA-116, STGA-134, ST-GB-18); 5 m2 (ST-GA-28, ST-GA-133, STGA-137, ST-GD-13, ST-GE-3); 7 m3 (ST-GA-139, STGA-140, ST-GB-21, ST-GB-22, ST-GB-24, ST-GE-4, STGE-5) (Tab. 1; Fig. 4).

\section{Description.}

M3. There are no roots. The teeth are hypsodont, with cement on the reentrant triangles. There is a great confluence between $\mathrm{T} 2$ and $\mathrm{T} 3$ and the second buccal triangle is slightly shorter than the other buccal triangles.

m1. Hypsodont teeth. It has three closed triangles (T1 to T3), whereas T4 and T5 are opposite and broadly confluent, creating a diamond-shaped dentine field called "pitymyan rhombus". This rhombus is inclined backwards. The anteroconid complex is formed also by two opposed and confluent triangles (T6, T7), creating a second rhombus that opens widely to an anterior lobe which is ovoid and rounded.

$\underline{\mathrm{m} 2}$. It has no roots. The teeth are hypsodont, with cement on the reentrant triangles. Tooth with four triangles and a posterior loop. T3 and T4 are confluent and the angles are not sharp.

m3. It has no roots. The teeth are hypsodont, with cement on the reentrant triangles. Tooth with four triangles and a posterior loop. T3 and T4 are confluent and the angles are not sharp. There is a big labiolingual asymmetry.

Remarks. The $\mathrm{m} 1$ have three closed triangles ( $\mathrm{T} 1$ to T3), whereas T4 and T5 are opposite and broadly confluent, creating a diamond-shaped dentine field called "pitymyan rhombus", typical of the subgenus Terricola. T6/T7 are displayed symmetrically and parallel like specimens of M. duodecimcostatus, differentiating from Microtus gerbii (Gerbe, 1879) with asymmetric and no parallel disposition of T6/T7 (Brunet-Lecomte \& Chaline, 1990). Together with the great confluence of T2-T3 (contrary to what it is seen on $M$. gerbei and the short second buccal triangle of the third upper molar are typical from the group of species Microtus sp. gr. M. duodecimcostatus-lusitanicus (Gosàlbez, 1987). The breadth of the anterior lobe $(\geq 0.4$ $\mathrm{mm}$ ) and the slope of the pitymyan rhombus in $\mathrm{m} 1$, which permits distinguishing both species, allow us to ascribe these specimens to the species Microtus duodecimcostatus (Brunet-Lecomte et al., 1987).

Family Muridae Fischer, 1817

Genus Apodemus Kaup, 1829

Apodemus sylvaticus (Linnaeus, 1758)

Material. 24 M1 (ST-GA-1 to ST-GA-6, ST-GA-8, STGA-121, ST-GA-122, ST-GA-124, ST-GB-5, ST-GB-36, ST-GB-89, ST-GB-90, ST-GC-49, ST-GD-1, ST-GD-4, ST-GD-30, ST-GE-17); 7 M2 (ST-GA-7, ST-GA-13, STGA-125, ST-GB-4, ST-GB-27, ST-GB-33, ST-GD-5); 2 M1-2 (ST-GB-37, ST-GB-94), 6 M3 (ST-GA-41, STGA-94, ST-GB-6, ST-GB-91, ST-GC-5, ST-GD-7); 2 Md (ST-GC-1, ST-GC-48a); $21 \mathrm{~m} 1$ (ST-GA-9 to ST-GA-11, ST-GA-117, ST-GA-119, ST-GB-1 to ST-GB-3, ST-GB-25, ST-GB-26, ST-GB-38, ST-GB-82, ST-GB-92, ST-GC-1b, ST-GC-2, ST-GC-3, ST-GC-48b, ST-GC-76, ST-GC-93, ST-GD-2, ST-GE-16); $11 \mathrm{~m} 2$ (ST-GA-12, ST-GA-14, STGA-15, ST-GA-120, ST-GB-80, ST-GB-93, ST-GC-1c, ST-GC-4, ST-GC-50, ST-GC-51, ST-GE-1); 1 m1-2 (STGD-3); 6 m3 (ST-GA-16, ST-GA-42, ST-GA-123, STGB-7, ST-GB-35, ST-GB-81) (Tab. 1; Fig. 4). 


\section{Description.}

M1. Brachydont and bunodont molars. All molars display $\mathrm{t} 4$ and $\mathrm{t} 7$ linked. 5 out of 8 specimens have $\mathrm{t} 1$ bis and two out of five have $\mathrm{t} 2$ bis, meanwhile six out of seven have a spur in $\mathrm{t} 3$.

$\underline{\mathrm{M}}$. Brachydont and bunodont molars. T9 is well developed. $\mathrm{t} 1$ and $\mathrm{t} 3$ are big and isolated. There are four roots.

M3. Brachydont and bunodont molars. The $\mathrm{t} 1$ is large and isolated. The $\mathrm{t} 3$ is absent. The $\mathrm{t} 4, \mathrm{t} 5, \mathrm{t} 6, \mathrm{t} 8$ and $\mathrm{t} 9$ are connected.

$\underline{\mathrm{m} 1}$. Brachydont and bunodont molars. The tma is welldeveloped. The anteroconid is symetric and linked to the metaconid by a narrow crest. The labial cingulum is well developed and it has a large round $\mathrm{cl}$ and one or two accesory cuspids. Big round or oval posterior heel shifted towards the lingual side of the molar. It has two roots.

$\underline{\mathrm{m}} 2$. Brachydont and bunodont molars. The anterolabial part is large and oval. The labial cingulum is poorly developed or absent. The posterior tubercle is big, round or oval and shift towards the lingual side. Two roots.

$\underline{\mathrm{m} 3}$. Brachydont and bunodont molars. The anterolabial cuspid is absent. There is no accessory cuspid. All the remains where it was possible to observe the c1 (2) display one.

Remarks. Differentiation between Apodemus sylvaticus and Apodemus flavicollis (Melchior, 1834) is complicated due to the similarity between the morphology and the measurements of the dentition. However, a study of the living populations made this discrimination possible (Pasquier, 1974). The relative length of the $\mathrm{m} 2$ (length/ width) and the percentage of M2 with a reduced t9 (Pasquier, 1974; Michaux \& Pasquier, 1974; Arrizabalaga et al., 1999) are the characters, which led to differentiate between both species. Meanwhile $A$. sylvaticus presents a well-developed $\mathrm{t} 9$ in $\mathrm{M} 2$, low values of the relative length of $\mathrm{m} 2$ and $\mathrm{t} 4-\mathrm{t} 7$ united in $\mathrm{M} 1$, A. flavicollis presents higher percentage of reduced $\mathrm{t} 9$ in $\mathrm{M} 2$, separation of $\mathrm{t} 4$ t7 in M1 and high values of the relative length of $\mathrm{m} 2$ (Michaux \& Pasquier, 1974; Arrizabalaga et al., 1999). The relative length of the $\mathrm{m} 2$ (length/width) (Tab. 1), the welldeveloped $\mathrm{t} 9$ in all M2and the union of $\mathrm{t} 4-\mathrm{t} 7$ in M1 led us to identified these remains as Apodemus sylvaticus (Fig. 6).

Family Gliridae Muirhead, 1819

Genus Eliomys Wagner, 1840

Eliomys quercinus (Linnaeus, 1766)

Material. 1 D4 (ST-GD-15); 1 P4 (ST-GC-52); 1 p4 (ST-GD-6); $1 \mathrm{~m} 1$ (ST-GA-40, ST-GB-8); $1 \mathrm{~m} 2$ (STGA-39); 2 m3 (ST-GB-28, ST-GD-16) (Tab. 1; Fig. 4).

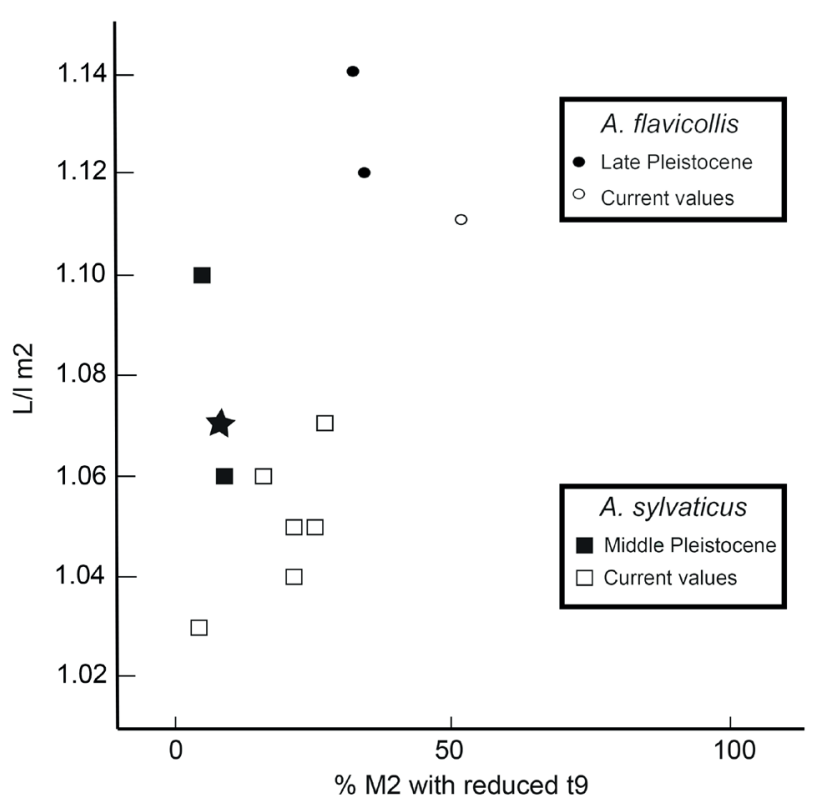

Figure 6. Relation between \% M2 with reduced $\mathrm{t} 9$ and relative length of $\mathrm{m} 2$ between current and fossil specimens from Apodemys sylvaticus and Apodemys flavicollis, as well as mean value for specimens from Units I-IV from El Salt site (black star) (modified from Michaux \& Pasquier, 1984).

\section{Description.}

D4. Brachydont and lophodont tooth. It has a subtriangular outline. The anteroloph is short and is connected at a low level to the paracone. The protoloph is continuous meanwhile the metaloph is discontinuous. There are no centrolophs. The posterior side is broken.

P4. Brachydont and lophodont tooth. It has a subtriangular outline. The anteroloph is short and is connected at a high level to the paracone. The protoloph and the metaloph are continuous. There are no centrolophs. The posteroloph is low and lingually connected to the protocone.

p4. Brachydont and lophodont tooth. It has a subtriangular outline. Worn tooth. The posterolophid is high and curved. It has two fused roots.

$\underline{\mathrm{m} 1}$. Brachydont and lophodont tooth. The anterolophid is continuous and connected to the protoconid. There is no anterotropid. There is no centrolophid neither posterotropid. The metaconid and the entoconid are separated by a narrow valley. The metalophid and mesolophid are continuous. The hypoconid is large.

$\underline{\mathrm{m} 2}$. Brachydont and lophodont tooth. The anterolophid is continuous and connected to the protoconid. There is no anterotropid. There is acentrolophid but the posterotropid is absent. The metaconid and the entoconid are separated by a wider valley than in $\mathrm{m} 1$. The metalophid and mesolophid are continuous. The hypoconid is large. 
$\underline{\mathrm{m}}$. Brachydont and lophodont teeth. Continuous anterolophid, in contact with the protoconid. The accessory crests are absent. There is no centrolophid. The postelophid is continuous. Labial part has become recently fragmented.

Remarks. Eliomys quercinus, Glis glis (Linnaeus, 1766) and Muscardinus avellanarius (Linnaeus, 1758) are the three species of glirids recorded in the Iberian Peninsula during the Late Pleistocene and the Holocene. The morphology observed in the specimens from El Salt is very similar to Eliomys quercinus: the surface is clearly concave and presents well developed cusps, low number of transverse ridges and any accessory crests in the lower molars. According to Ruiz Bustos et al. (1982) and Paunesco \& Abbassi (2002), these morphologies are diagnostic features of the species E. quercinus.

\section{RESULTS AND DISCUSSION}

\subsection{Taxa identified}

Unit I to Unit IV of El Salt site have provided a NISP of 323 encompassing 16 taxa and a total MNI of 74. Seven rodents (Arvicola sapidus, Microtus sp., M. arvalis, $M$. cabrerae, M. duodecimcostatus, Apodemus sylvaticus, and Eliomys quercinus), one lagomorph (Oryctolagus cuniculus), two insectivores (Crocidura sp. and Sorex sp.), one toad (Epidalea calamita), two lizards (Lacertidae indet. and Chalcides cf. bedriagai) and three snakes (Serpentes indet. Coronella $\mathrm{cf}$. girondica, and cf. Coronella sp.) have been identified (Tab. 2). The most represented species in the assemblageis A. sylvaticus with a total MNI of 17 , followed by Oryctolagus cuniculus with 11 (Tab. 2).

Comparing the fossil assemblage with the present-day small vertebrate taxonomic spectrum in the Alcoi valleys, the species $M$. cabrerae, $M$. arvalis, $A$. sapidus, and species from the genus Sorex are absent today (Palomo et al., 2007). Anthropogenic and climatic factors (high temperatures and low rainfall) could explain this difference (Guillem, 1995, 2001). Regarding the herpetofauna, all the taxa described are present in the region today (AHE, 2020).

In the analyzed deposit, other remains with ecological interest have been found. Remains of gastropods and bivalves were also found, reaching a total of 22 taxa. Gastropods are represented by 21 taxa while only one bivalve has been determined. Fourteen taxa correspond to terrestrial gastropods: Oxyloma elegans, Ferussacia folliculus, Ceciloides acicula, Punctum pygmaeum, Oligolimax annularis, Vallonia costata, Chondrina sp., Rumina decollata, Xerocrassa subrogata, Cochlicella sp., Monacha cartusiana, Iberus alonensis, and Pseudotachea
Table 2. Number of Identified Specimens (NISP), Minimum Number of Individuals (MNI) of small vertebrates from the gravelly deposit of El Salt (Alcoi).

\begin{tabular}{lrcc}
\hline Taxon & NISP & MNI & \% \\
\hline Coronella cf. girondica & 1 & 1 & 1.35 \\
Chalcides cf. bedriagai & 22 & 3 & 1.35 \\
Epidalea calamita & 2 & 1 & 4.05 \\
Sorex sp. & 2 & 1 & 1.35 \\
Crocidura sp. & 5 & 3 & 4.05 \\
Oryctolagus cuniculus & 99 & 12 & 16.22 \\
Arvicola sapidus & 5 & 2 & 2.70 \\
Microtus sp. & 30 & & \\
Microtus arvalis & 38 & 14 & 18.92 \\
Microtus cabrerae & 15 & 5 & 6.76 \\
Microtus duodecimcostatus & 20 & 11 & 14.86 \\
Apodemus sylvaticus & 74 & 17 & 22.97 \\
Eliomys quercinus & 10 & 4 & 5.41 \\
Total & $\mathbf{3 2 3}$ & $\mathbf{7 4}$ & $\mathbf{1 0 0}$ \\
\hline
\end{tabular}

splendida. Five out of the 21 gastropod taxa are freshwater species: Theodoxus meridionalis, Josefus aitanica, Ancylus fluviatilis, Gyraulus laevis, and Lymnaeidae spp. Bivalves are represented by the species Pisidium casertanum. The taxa identified are similar to the current taxa in the region (Gasull, 1971, 1975; Pujante et al., 1998; Martínez-Ortí, 1999, 2006, 2014; Martínez-Ortí \& Robles, 2003). The presence of fresh-water gastropods and bivalves denotes the existence of water bodies in the surrounding areas of the site.

Regarding the anthracological remains, a total of 7 taxa have been identified: Juniperus sp., Pinus nigrasylvestris, evergreen and deciduous Quercus, SalixPopulus, Fabaceae and Maloideae. Excluding Pinus nigrasylvestris, which is very few represented in the current local landscape, the other taxa are present in the region nowadays. The homogeneous anatomical structure of Juniperus means that it cannot be identified at the species level, although the identification of seeds from Juniperus sabina in units VIII and Xa confirms that at least this species was present during the Middle Palaeolithic period. Despite the fact that this anthracological record could be reworked, the identified taxa show similarities with anthracological sequences from several sites of the region focused on the Late Glacial like Cova de les Cendres (Moraira, Alicante) (Badal, 1990; Badal \& Carrión, 2001), Tossal de la Roca (Vall d'Alcalà, Alicante) (Uzquiano, 1988), Ratlla del Bubo (Badal, 1990) or Coves de Santa Maira (Castell de Castells, Alicante) (Aura et al., 2005; Carrión, 2005). 


\subsection{Biochronology}

The resulting vertebrate assemblage is characteristic of the Late Pleistocene and the Late Pleistocene-Holocene transition. All the species that appear in the deposit analysed are present in the Iberian Peninsula from the beginning of the Late Pleistocene onwards (Sesé, 2005; López-García et al., 2011). Microtus cabrerae constitutes the species with the shortest time range as its first populations were recorded in Middle-Late Pleistocene transition localities of southern France (Laplana \& Sevilla, 2013). For its part, although the species Microtus duodecimcostatus has been recorded in the Iberian Peninsula since the Middle Pleistocene (López-Martínez \& Ruiz-Bustos, 1977), the representatives of the subgenus Terricola are absent in the Mediterranean zone until the Late Pleistocene (Guillem, 1995; López-García et al., 2008, 2012).

Another relevant taxon from a biochronological point of view is Microtus arvalis. This species was only distributed at the mountainous ranges of the northern half of the Iberian Peninsula (Cordillera Cantábrica, Sistema Central, Sistema Ibérico and Pirineos) until 1960-1970, when this species began to colonize agricultural plains of Castilla y León due to irrigated crops in these suboptimal areas (Luque-Larena et al., 2013). It mainly occupies the Supramediterranean belt and it is absent in Mediterranean zones (Rivas Martínez, 1987; Fernández-Salvador, 2007). The fossil record in the Iberian Peninsula for this species and others with Eurosiberian requirements shows that their distribution contracted around the Pleistocene-Holocene transition $(<14.7 \mathrm{ka} \mathrm{BP})$, coinciding with a climatic change toward higher temperatures and increased rainfall, which ensued landscape modifications throughout the Iberian Peninsula (Carrión et al., 2010; Fernández-García et al., 2016). Accordingly, different sites in the studied region (southeastern of the Iberian Peninsula) show the presence of M. arvalis in Pleistocene levels, such as Cova Bolumini (level V) (Guillem et al., 1992), Cueva de San Antón (Sarrión, 1982), Cova de les Cendres (lower part of Unit V) (Guillem, 2001), Tossal de la Roca (levels I-IV “Corte Interior") (Cacho et al., 1995). However, it is absent in levels and sites dated to the Holocene, such as Abric de la Falguera (Guillem, 2006), Cingle de l'Aigua (Villaverde et al., 2010), Bolumini (levels I-IV) (Guillem et al., 1992), Cendres (since the upper part of Unit V) (Tormo-Cunat, 2010), Cova Fosca (Sesé, 2011), Cova de l'Or (Arribas, 2004) or Cova de la Sarsa (Sevilla, 1988). Thus, the disappearance of $M$. arvalis from this territory can be dated to $13.320 \pm 0.170 \mathrm{ka} \mathrm{BP}$ or between $13.320 \pm 0.170 \mathrm{ka} \mathrm{BP}$ (Cova de les Cendres) and $10.520 \pm 0.06 \mathrm{ka}$ BP (Cingle de L'Aigua). In other regions such as northeastern Iberian Peninsula, a contraction in the presence of $M$. arvalis and related species has also been documented (López-García et al., 2015; Fernández-García et al., 2016).
The biochronological significance of the presence of $M$. arvalis at the studied units is inconsistent with the presence of pottery at these deposits, which indicate that their age is at most seven millennia before present, which is the chronology for the first records of pottery in this territory. The remainder species are not incompatible from a biochronological point of view with the age indicated by pottery for the El Salt gravelly levels. However, its preservation, similar to that of the remains of $M$. arvalis, suggests that they may have the same origin. Consequently, the remains of $M$. arvalis and most of the small-vertebrate remains recovered should be considered reworked elements from older sediments, most likely from Late Pleistocene or early Holocene. These older sediments were probably eroded and its paleontological content incorpored to younger deposit. Despite the fact that the anthracological record could be reworked too, the identified taxa show similarities with anthracological sequences from several sites of the region focused on the end of the Late Glacial, such as Cova de les Cendres (Moraira, Alicante) (Badal, 1990; Badal \& Carrión, 2001), Tossal de la Roca (Vall d'Alcalà, Alicante) (Uzquiano, 1988), Ratlla del Bubo (Crevillente, Alicante) (Badal, 1990) or Coves de Santa Maira (Castell de Castells, Alicante) (Aura et al., 2005; Carrión, 2005).

The appreciation of the reworked character of all or part of the small-mammals' assemblage from the gravelly unit of El Salt site is consistent with the archaeological record present in these units, where archaeological materials indicative of different chronologies are mixed (Galván et al., 2014).

Reworking constitutes a taphonomic process that implies unearthing and transport of past biological entities (Fernández López, 2000). As a result of the transport of any remain, rounding and polishing (abrasion), disarticulation and even the production of linear marks are expected to be found in an assemblage that has suffered a process of transport. The existence of reworked material can be pointed out by some of the evidences already mentioned for transport as well as the coexistence of conservation differences between the different elements that constitute the studied sample (Fernández-Jalvo \& Andrews, 2016; and references therein). Evidences of rounding in breakage edges and protrusions, polishing and brightness have been observed in the assemblage analysed that suggests a taphonomic alteration that includes at least transport (Fig. 7). Further taphonomical and geoarchaeological work is needed to clarify the provenience of the studied faunal assemblages, which, given the high energy, erosional morphology and lithology of the sedimentary deposit, could have been reworked in more recent time periods.

Taking into account the reworked character of the smallmammals remains studied here, which is also extensive to the archaeological record contained in the studied units, we discard the possibility of carrying out a palaeoclimatic and/or palaeoenvironmental reconstructions, either with 


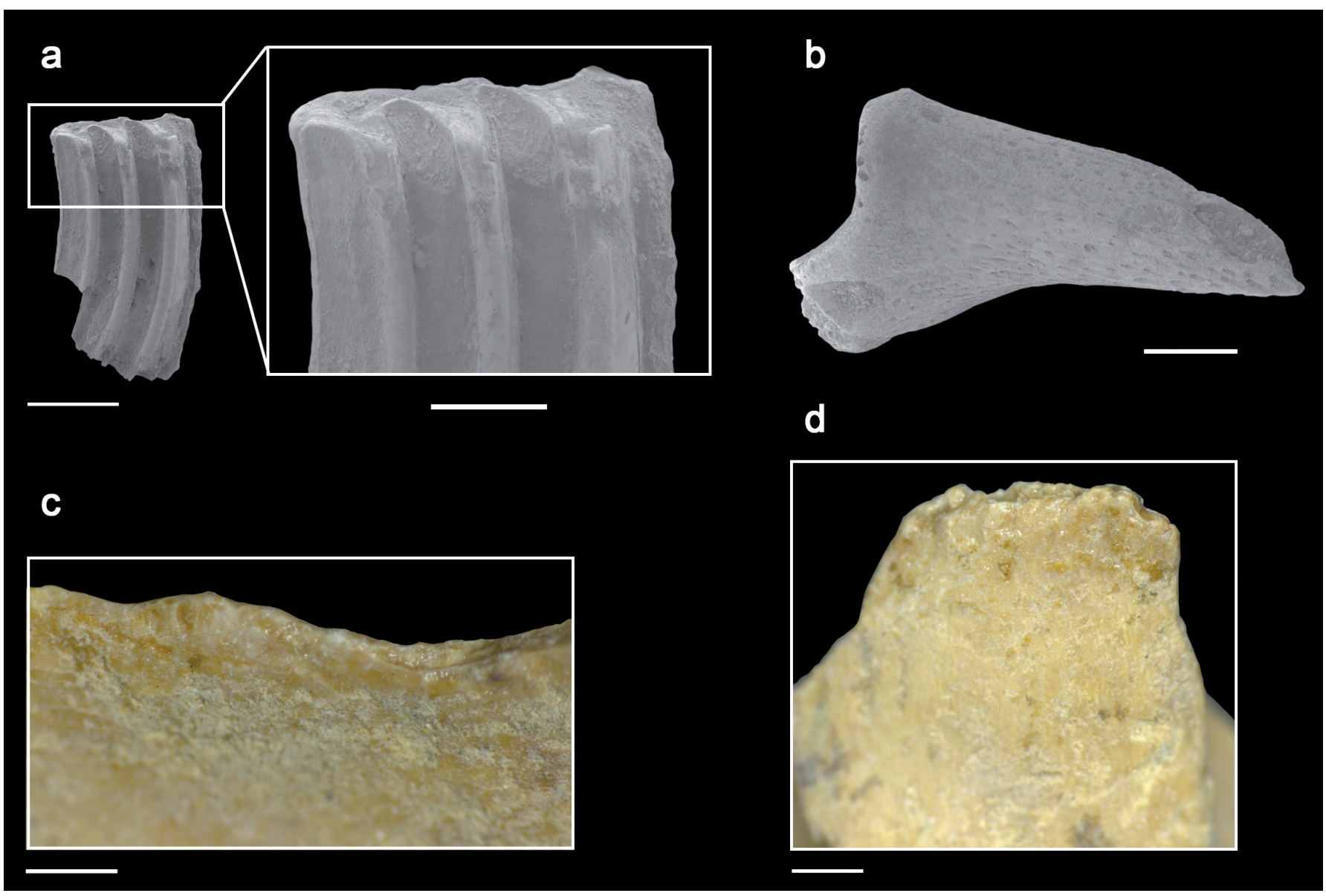

Figure 7. a) SEM microphotograph of abraded molar of an arvicolid showing enamel and dentine equally rounded on the salient angles of the tooth. b) SEM microphotograph of abraded phalange displaying rounded surface on the articulation and the fracture on the distal epiphysis. c-d) Brightness, polishing and rounded ends of a vertebra. Scale bar equal $1 \mathrm{~mm}$, except magnification on section (a), which corresponds to $0.5 \mathrm{~mm}$.

woody or vertebrate' taxa that may be representative of the environmental conditions that existed during the deposit of these units.

It is worth to note that, in the absence of archaeological record or absolute dates obtained on the sediment, it would have been very difficult to recognize the reworked character of a part, if not all, of the small-mammal assemblage. In this sense, this work emphasizes the need to establish clear criteria for reworking in smallvertebrate' assemblages, which can be used in these situations. The material studied will give rise to future work in this regard.

\section{CONCLUSIONS}

This study of the small vertebrates from the gravelly deposit at El Salt site allowed us to draw the following conclusions:
1) The small vertebrate assemblage is composed by seven rodent species (Arvicola sapidus, Microtus sp., M. arvalis, M. cabrerae, M. duodecimcostatus, Apodemus sylvaticus, and Eliomys quercinus), one lagomorph species (Oryctolagus cuniculus), two insectivore species (Crocidura sp. and Sorex sp.), one toad (Epidalea calamita), two lizard species (Lacertidae indet. and Chalcides cf. bedriagai), and two snake species (Coronella cf. girondica and cf. Coronella sp.). The most represented species is A. sylvaticus followed by Oryctolagus cuniculus.

2) The contradiction between the biochronological meaning of some of the small-mammal species identified with part of the archaeological content (Neolithic pottery), together with the homogeneous conservation of the remains force us to consider that most of the material analysed has been reworked and therefore it is not suitable for carrying out reliable climatic or environmental reconstructions for the moment of the formation of this deposit. 


\section{ACKNOWLEDGEMENTS}

This work has been possible thanks to the Sociedad Española de Paleontología who has funded this project. Also, research at El Salt is funded by the Spanish Government project HAR2015-68321-P (MINECO FEDER/UE), Conselleria d'Educació, Investigació, Cultura i Esports and Museu Arqueològic Camil Visedo Moltó. The authors want to thank the editor Dr. Carlos Martínez Pérez (Universitat de València, Valencia, Spain) and reviewers Dr. Sandra Bañuls Cardona (Universitat Rovira i Virgili, Tarragona, Spain) and Dr. Mónica Fernández García (Universitat Rovira i Virgili, Tarragona, Spain) for the corrections, suggestions and the constructive comments.

\section{BIBLIOGRAPHY}

Aguilar, J.P., Legendre, S. \& Michaux, J. 1997. Actes du Congres BiochroM'97. Memoires et travaux École practique de Hautes Études, Institut de Montpellier, 21, 769-805.

Agustí, J., Moyà-Solà, S. \& Pons-Moyà, J. 1987. La sucesión de mamíferos en el Pleistoceno Inferior de Europa: proposición de una nueva escala bioestratigráfica. Paleontologia i Evolució, 1, 287-295.

AHE 2020. SIARE (Servidor de Información de Anfibios y Reptiles de España). https://siare.herpetologica.es/.

Andrews, P. 1990. Owls, Caves and Fossils. The Natural History Museum, London.

Arribas, O. 2004. Fauna y Paisaje de los Pirineos en la Era Glaciar. Lynx, Barcelona.

Arrizabalaga, A., Torre Coromines, I., Catzeflis, F., Renaud, F. \& Santalla Quilles, F. 1999. Primera citació d'Apodemus flavicollis (Melchior, 1834) al Montseny. Determinaciómorfològica i genètica. III i IV Trobada d'Estudiosos del Montseny, 193-195.

Auffenberg, W. 1967. The fossil snakes of Florida. Tulane Studies in Zoology, 10, 131-216.

Aura, J., Carrión, Y., Estrelles, E. \& Jordá, G. 2005. Plant economy of hunter gatherer groups at the end of the last Ice Age: Plant macroremains from the Cave of Santa Maira (Alacant, Spain) ca. 12000-9000 B.P. Vegetation History and Archaeobotany, 14, 542-550; doi: 10.1007/ s00334-005-0002-1.

Ayarzagüena, J. \& López-Martínez, N. 1976. Estudio filogenético y comparativo de Microtus cabrerae y Microtus brecciensis. Doñana, 3, 181-204.

Badal, E. 1990. Aportaciones de la antracología al estudio del paisaje vegetal y su evolución en el Cuaternario reciente, en la costa mediterránea del País Valenciano y Andalucía (18.000-3.000 BP). PhD. Thesis, Universitat de València (unpublished).

Badal, E. \& Carrión, Y. 2001. Del glaciar al interglaciar: los paisajes vegetales a partir de los restos carbonizados hallados en las cuevas de Alicante. In: De Neandertales a Cromañones. El Inicio del Poblamiento Humano en las Tierras Valencianas (ed. Villaverde, V.). Universitat de València, Valencia, 21-40.

Bailon, S. 1991. Amphibiens et Reptiles du Pliocene et de du Quaternaire de France et d'Espagne: Mise en Place et Evolution des Faunes. PhD. Thesis, Université Paris VII (unpublished).

Bailon, S. 1999. Différenciation ostéologique des anoures (Amphibia, Anura) de France. In: Fiches d'Óstéologie Animale pour l'Archéologie. Série C: Varia (eds. Desse, J. \& Desse-Berset, N.). Antibes, Centre de Recherches Archéologiques - CNRS, 3-41.

Bailon, S. 2000. Amphibiens et reptiles du Pliocène terminal d'Ahl al Oughlam (Casablanca, Maroc). Geodiversitas, 22, 539-558.

Barahona, F. 1996. Osteología Craneal de Lacértidos de la Península Ibérica e Islas Canarias: Análisis Sistemático Filogenético. PhD. Thesis, Universidad Autónoma de Madrid (unpublished).

Barahona, F. \& Barbadillo, L.J. 1997. Identification of some Iberian lacertids using skull characters. Revista Española de Herpetología, 11, 47-62.

Barbadillo, L.J. 1989. Los reptilia (Sauria y Amphisbaenia) de los yacimientos Plio-Pleistocénicos de la Cuenca de Guadix-Baza. In: Geología y Paleontología de la Cuenca de Guadix-Baza. Trabajos Neógeno/Quaternario (eds. Alberti, M.T. \& Bonadonna, F.P.). Museo Nacional de Ciencias Naturales, Madrid, 151-165.

Bateson, W. 1885. The later stages in the development of Balanoglossus kowalevskii, with a suggestion as to the affinities of the Enteropneusta. Quarterly Journal of Microscopical Science, 25, 81-122.

Berggren, W.A. \& Van Couvering, J.A. 1978. Biochronology. In: Contribution to the Geologic Time Scale (eds. Cohee G.V., Glaessner, M.F. \& Hedberg, H.D.). American Association of Petroleum Geologists, 50, 1487-1500.

Bisbal-Chinesta, J.F. \& Blain, H.-A. 2018. Long-term changes in composition and distribution patterns in the Iberian herpetofaunal communities since the latest Pleistocene. Quaternary Science Reviews, 184, 143-166; doi: 10.1016/j.quascirev.2017.06.010.

Blain, H.-A. 2009. Contribution de la paléoherpétofaune (Amphibia \& Squamata) à la connaissance de l'évolution du climat et du paysage du Pliocène supérieur au Pléistocène moyen d'Espagne. Treballs del Museu de Geologia de Barcelona, 16, 39-170.

Blain, H.-A., Bailon, S., Agustí, J., Martínez-Navarro, B. \& Toro, I. 2011. Paleoenvironmental and paleoclimatic proxies to the Early Pleistocene hominids of Barranco León D and Fuente Nueva 3 (Granada, Spain) by means of their amphibian and reptile assemblages. Quaternary International, 243, 44-53; doi: 10.1016/j. quaint.2010.12.031.

Blay García, F. 1992. Cueva Merinel (Bugarra). Análisis de la Fauna. In: Estudios de Arqueología Ibérica y Romana. Homenaje a Enrique Pla Ballester. Serie de Trabajos Varios, 89. Diputación Provincial de Valencia, 283-87. 
Boessneck, J. 1974. Ergänzungen zur einstigen Verbreitung des Bibers, Castor fiber (Linné, 1758). Säugetierkundliche Mitteilungen, 22, 83-88.

Boscá, E. 1880. Gongylus bedriagai, nueva subespecie de la península Ibérica. Anales de la Sociedad Española de Historia Natural, 9, 495-503.

Bowdich, T.E. 1821. An Analysis of the Natural Classifications of Mammalia: for the Use of Students and Travellers. J. Smith, Paris.

Brandt, J.F. 1855. Beiträge zur nähern Kenntniss der Säugethiere Russlands. Buchdruckerei der Kaiserlichen Akademie der Wissenschaften St.-Pétersbourg.

Brunet-Lecomte, P. \& Chaline, J. 1990. Relations phylogénétiques et evolution des campagnols souterrains d'Europe (Terricola, Arvicolidae, Rodentia). Comptes Rendus de l'Académie des Sciences, Paris, 311, 745-750.

Brunet-Lecomte, P., Brochet, G., Chaline, J. \& Delibes, M. 1987. Morphologie dentaire comparée de Pitymys lusitanicus et $P$. duodecimcostatus (Arvicolidae, Rodentia) dans le nord-ouest de l'Espagne. Mammalia, 51, 145-158; doi: 10.1515/mamm.1987.51.1.145.

Cacho, C., García, M.P.F., López, P., López, J.A., Ripoll, M.P., Valle, R.M., Uzquiano, P., Arnanz, A., SánchezMarco, A., Sevilla, P., Morales, A., Roselló, E., Garralda, M.D. \& García-Carrillo, M. 1995. El Tossal de la Roca (Vall d'Alcalá, Alicante). Reconstrucción paleoambiental y cultural de la transición del tardiglaciar al Holoceno inicial. Recerques del Museud'Alcoi, 4, 11-101.

Callou, C. 1997. Diagnose différentielle des principaux éléments squelettiques du lapin (genre Oryctolagus) et du lièvre (genre Lepus) en Europe occidentale. Fiches d'Ostéologie Animale pour l'Archéologie, Série B, Mammifères, 8, 1-23.

Caputo, V. 2004. The cranial osteology and dentition in the scinicid lizards of the genus Chalcides (Reptilia, Scincidae). Italian Journal of Zoology, 71, 35-45; doi: 10.1080/11250000409356604.

Carrión, Y. 2005. La Vegetación Mediterránea y Atlántica de la Península Ibérica: Nuevas Secuencias Antracológicas. Servicio de Investigación Prehistórica. Diputación Provincial de Valencia. Trabajos Varios , 104.

Carrión, J.S., Fernández, S., González-Sampériz, P., GilRomera, G., Badal, E., Carrión-Marco, Y., López-Merino, L., López-Sáez, J.A., Fierro, E. \& Burjachs, F. 2010. Expected trends and surprises in the late glacial and Holocene vegetation history of the Iberian Peninsula and Balearic Islands. Review of Palaeobotany and Palynology, 162, 458-475; doi: 10.1016/j.revpalbo.2009.12.007.

Chaline, J. 1972. Les Rongeurs du Pléistocène Moyen et Supérieur de France. (Systématique, Biostratigraphie, Paléoclimatologie). Éditions du Centre National de la Recherche Scientifique, Paris.

Cope, E.D. 1864. Contributions to the herpetology of tropical America. Proceedings of the Academy of Natural Sciences of Philadelphia, 16, 166-181.

Crespo, V.D., Manzanares, E., Montoya, P. \& RuizSánchez, F.J. 2016. What is a Cretaceous sawfish in a Miocene forest? In: New Perspectives on the Evolution of Phanerozoic Biotas and Ecosystems. Conference Proceedings, Ayuntamiento de Alpuente, p. 182.

Cucchi, T., Vigne, J.D., \& Auffray, J.C. 2005. First occurrence of the house mouse (Mus musculus domesticus Schwarz \& Schwarz, 1943) in the western Mediterranean: a zooarchaeological revision of subfossil occurrences. Biological Journal of the Linnean Society, 84, 429-445; doi: 10.1111/j.1095-8312.2005.00445.x.

Cuenca-Bescós, G., Straus, L.G. \& Morales, M.R.G. 2008. Paleoclima y paisaje del final del Cuaternario en Cantabria: los pequeños mamíferos de la Cueva del Mirón (Ramales de la victoria). Revista Española de Paleontología, 23, 91-126.

Daams, R. 1981. The dental pattern of the dormice Dryomys, Myomimus, Microdyromys and Peridyromys. Utrecht Micropaleontological Bulletins, Special Publication, 3, $1-115$.

Daudin, F.M. 1803. Histoire Naturelle, Générale et Particulière des Reptiles, Vol. 4. F. Dufart, Paris.

De Marfà, R. 2009. Els lagomorfs (O. Lagomorpha, Cl. Mammalia) del Pliocè i Pleistocè europeus. Ph.D Thesis, Universitat Rovira i Virgili (unpublished).

De Sélys-Longchamps, E. 1839. Etudes de Micromammalogie. Revue des Musaraignes, des Rats et des Campagnols, Sivie d'une Index Methodique des Mammiferes d'Europe. Librairie Encyclopedique de Roret, Paris.

Domínguez García, Á.C., Laplana, C., Sevilla, P., Blain, H., Palomares Zumajo, N. \& Benítez de Lugo Enrich, L. 2019. New data on the introduction and dispersal process of small mammals in southwestern Europe during the Holocene: Castillejo del Bonete site (southeastern Spain). Quaternary Science Reviews, 225, 106008; doi: 10.1016/j. quascirev.2019.106008.

Donard, E. 1982. Recherches sur les léporidés quaternaires (Pléistocène moyen et supérieur, Holocène). $\mathrm{PhD}$. Thesis, Université Bordeaux (unpublished).

Donovan, S.K., Blissett, D.J. \& Jackson, T.A. 2010. Reworked fossils, ichnology and palaeoecology: an example from the Neogene of Jamaica. Lethaia, 43, 441-443; doi: 10.1111/j.1502-3931.2010.00215.x.

Duméril, A.M.C. 1806. Zoologie Analytique, ou Méthode Naturelle de Classification des Animaux, Rendue plus Facile à l'Aide de Tableaux Synoptiques. Allais, Paris.

Fagoaga, A., Ruiz-Sánchez, F.J., Laplana, C., Blain, H.A., Marquina, R., Marin-Monfort, M.D. \& Galván, B. 2018. Palaeoecological implications of Neanderthal occupation at Unit $\mathrm{Xb}$ of El Salt (Alcoi, eastern Spain) during MIS 3 using small mammals proxy. Quaternary International, 481, 101-112; doi: 10.1016/j.quaint.2017.10.024.

Fagoaga, A., Laplana, C., Marquina, R., Machado, J., Marin-Monfort, M.D., Crespo, V.D., Hernández, C., Mallol, C., Galván, B. \& Ruiz-Sánchez, F.J. 2019. Palaeoecological context for the extinction of the Neanderthals: a small mammal study of Stratigraphic Unit V of the El Salt site, Alcoi, eastern Spain. Palaeogeography, Palaeoclimatology, Palaeoecology, 530, 163-175; doi: 10.1016/j.palaeo.2019.05.007.

Fatio, V. 1867. Les Campagnols du Bassin du Léman. Georg, Paris. 
Fernández-García, M., López-García, J.M. \& Lorenzo, C. 2016. Palaeoecological implications of rodents as proxies for the Late Pleistocene-Holocene environmental and climatic changes in northeastern Iberia. Comptes Rendus Palevol, 15, 707-719; doi: 10.1016/j.crpv.2015.08.005.

Fernández-Jalvo, Y., Andrews, P. 1992. Small mammal taphonomy of Gran Dolina, Atapuerca (Burgos). Spain. Journal of Archaeological Sciences, 19, 407-428; doi: 10.1007/978-94-017-7432-1.

Fernández-Jalvo, Y. \& Andrews, P. 2016. Atlas of Taphonomic Identifications: 1001+ Images of Fossil and Recent Mammal Bone Modification. Springer, New York.

Fernández López, S. 1991. Taphonomic concepts for a theoretical biochronology. Revista Española de Paleontología, 6, 37-49.

Fernández López, S. 2000. Temas de Tafonomía. Departamento de Paleontología, Facultad de Ciencias Geológicas, Madrid.

Fernández-Salvador, R. 2007. Microtus cabrerae (Thomas, 1906). In: Atlas y Libro Rojo de los Mamíferos Terrestres de España (eds. Palomo, L.J., Gisbert, J. \& Blanco, J.C.). Dirección General para la Biodiversidad -SECEMSECEMU, Madrid. 429-433.

Fischer, G. 1817. Adversaria zoologica. Mémoires de la Société impériale des naturalistes de Moscou, 5, 357-472.

Freudenthal, M. 2004. Gliridae (Rodentia, Mammalia) from the Eocene and Oligocene of the Sierra Palomera (Teruel, Spain). Treballs del Museu de Geologia de Barcelona, 12, 97-173.

Frost, D.R. 2015. Amphibian Species of the World: an Online Reference. Version 6.0. http://research.amnh.org/ herpetology/amphibia/index.html.

Fumanal, M.P. 1986. Sedimentología y Clima en el País Valenciano. Las Cuevas Habitadas en el Cuaternario Reciente. Diputación Provincial de Valencia, Valencia.

Fumanal, M.P. 1994. El yacimiento musteriense de El Salt (Alcoi, País Valenciano). Rasgos geomorfológicos y climatoestratigrafía de sus registros. Saguntum, 27, 39-55.

Fumanal, M.P. 1995. Los depósitos cuaternarios en cuevas y abrigos. Implicaciones sedimentológicas. In: $E l$ Cuaternario en el País Valenciano. Asociación Española para el Estudio del Cuaternario - Universitat de València, Valencia, 115-124.

Furió, M. 2007. Los insectívoros (Soricomorpha, Erinaceomorpha, Mammalia) del Neógeno Superior del Levante Ibérico. PhD. Thesis, Universitat Autònoma de Barcelona (unpublished).

Galván, B., Hernández, C.M., Mallol, C., Mercier, N., Sistiaga, A. \& Soler, V. 2014. New evidence of early neanderthal disappearance in the Iberian Peninsula. Journal of Human Evolution, 75, 16-27; doi: 10.1016/j. jhevol.2014.06.002.

Garralda, M.D., Galvan, B., Hernández, C.M., Mallol, C., Gómez, J.A. \& Maureille, B. 2014. Neanderthals from El Salt (Alcoi, Spain) in the context of the latest Middle Palaeolithic populations from the southeast of the Iberian Peninsula. Journal of Human Evolution, 75, 1-15; doi: 10.1016/j.jhevol.2014.02.019.
Gasull, L. 1971. Fauna malacológica de las aguas continentales, dulces y salobres del Sudeste ibérico. Boletín de la Sociedad de Historia Natural de Baleares, 16, 23-93.

Gasull, L. 1975. Fauna malacológica terrestre del sudeste ibérico. Boletín de la Sociedad de Historia Natural de Baleares, 20, 1-155.

Gerbe, J.-J.Z. 1879. Diagnose d'un campagnol nouveau de France. Le Naturaliste: journal des échanges et des nouvelles, 7, 51.

Gosàlbez, J. 1987. Insectívors i Rosegadors de Catalunya. Metodologia d'Estudi i Catàleg Faunístic. Ketres Editora, Barcelona.

Gray, J.E. 1821. Outline of an attempt at the disposition of the Mammalia into tribes and families with a list of the genera apparently appertaining to each tribe. Annals of Philosophy, 10, 337-344.

Gray, J.E. 1825. A synopsis of the genera of Reptiles and Amphibia, with a description of some new species. Annals of Philosophy. Series 2, 10, 193-217.

Guillem, P.M. 1995. Bioestratigrafía de los micromamíferos (Rodentia, Mammalia) del Pleistoceno Medio, Superior y Holoceno del País Valenciano. Saguntum, 38, 11-18.

Guillem, P.M. 2001. Los micromamíferos y la secuencia climática del Pleistoceno medio, Pleistoceno superior y Holoceno en la fachada central mediterránea. In: De Neandertales a Cromañones. El Inicio del Poblamiento Humano en las Tierras Valencianas (ed. Villaverde, A.). Universitat de València, Valencia, 57-72.

Guillem, P.M. 2006. Los micromamíferos (Insectivora, Rodentia y Chiroptera) del Abric de la Falguera, un pequeño fragmento de la historia de la vida. In: El Abric de La Falguera (Alcoi, Alacant). 8.000 Años de Ocupación Humana en la Cabecera del Río de Alcoi (eds. García Puchol, O. \& Aura Tortosa, J.E.). Museo Arqueológico de Alicante, Alicante, 118-123.

Guillem, P.M., Guitart Perarnau, I., Martínez Valle, R., Mata Parreño, C. \& Pascual Benito, J.L.L. 1992. L’ocupació prehistórica de la Cova de Bolumini (BeniarbeigBenimeli-Marina Alta). III Congrés d'Estudis de la Marina Alta, Actas, p. 31-49.

Hermann, J. 1780. Crocidura russula. Geographische Geschichtedes Menschen (ed. Zimmermann, E.A.W), 2. Leipzig.

Hoffstetter, R. \& Gasc, J.-P. 1969. Vertebrae and Ribs of Modern Reptiles. In: Biology of the Reptilia. Volume 1. Morphology A (eds. Gasc, C., Bellairs, A.d'A. \& Parsons, T.S.). Academic Press, London, 201-310.

Hontecillas, D., Houssaye, A., Laplana, C., Sevilla, P., Arsuaga, J.L., Pérez-González, A., Baquedano, E. \& Knoll, F. 2015. Reworked marine pythonomorph (Reptilia, Squamata) remains in Late Pleistocene cave deposits in central Spain. Cretaceous Research, 54, 188-202; doi: 10.1016/j.cretres.2014.12.010.

Iborra Eres, M.P. \& Martínez del Valle, R. 2009. La fauna de los niveles neolíticos de la Cova de les Cendres. In: La Cova de Les Cendres (eds. Bernabeu Aubán, J. \& Molina Balaguer, L.). Museo Arqueológico de Alicante, Alicante, 149-162. 
Jaarola, M., Martínkova, N., Günduz, I., Brunhoff, C., Zima, J., Nadachowski, A., Amori, G., Bulatova, N.S., Chondropoulos, B., Fraguedakis-Tsolis, S., González Esteban, J., López-Fuster, M.J., Kandaurov, A.S., Kefelioglu, H., Mathias, M.L., Villate, I. \& Searle, J. 2004. Molecular phylogeny of the species vole genus Microtus (Arvicolinae, Rodentia) inferred from mitochrondrial DNA sequences. Molecular Phylogenetics Evolution, 33, 647-663; doi: 10.1016/j.ympev.2004.07.015.

Jammot, D. 1974. Les insectivores de Cagny (Somme). Soricidae (Insectivora, Mammalia). Bulletin de l'Association Française des Études du Quaternaire, 11, $187-189$.

Jeannet, M. 2000. Gruta da Figueira Brava. Les rongeurs. Memórias da Academia das Ciências de Lisboa, 38, 179-243.

Kaup, J.J. 1829. Skizzirte Entwickelungs-Geschichte und Natürliches System der Europäischen Thierwelt. Leske, Darmstadt.

Lacépède, B.G.E. 1799. Tableau des divisions, sousdivisions, orders et genres des mammiferes. In: Discours d'Ouverture et de Cloture du Cours d'Histoire Naturelle: l'an VII de la République, et Tableaux Methodiques des Mammifères et des Oiseaux. Plassan, Paris, 1-120.

Laplana, C. \& Sevilla, P. 2013. Documenting the biogeographic history of Microtus cabrerae through its fossil record. Mammal Review, 43, 309-332; doi: 10.1111/mam.12003.

Laurenti, J.N. 1768. Specimen Medicum, Exhibens Synopsin Reptilium Emendatum cum Experimentis Circa Venena et Antidota Reptilium Austriacorum. Joan Thomae, Wien.

Leierer, L., Jambrina-Enríquez, M., Herrera-Herrera, A.V., Connolly, R., Hernández, C.M., Galván, B. \& Mallol, C. 2019. Insights into the timing, intensity and natural setting of Neanderthal occupation from the geoarchaeological study of combustion structures: a micromorphological and biomarker investigation of El Salt, unit Xb, Alcoy, Spain. PLoS ONE, 14, e0214955; doi: 10.1371/journal. pone. 0214955.

Lindsay, E. 2003. Chronostratigraphy, biochronology, datum events, land mammal ages, stage of evolution, and appearance event ordination. Bulletin of the American Museum of Natural History, 279, 212-230.

Linnaeus, C. 1758. Systema Naturae per Regna Tria Naturae, Secundum Classes, Ordines, Genera, Species, cum Characteribus, Differentiis, Synonymis, Locis. 10th Edition. Volume 1. Holmiae, Impensis Laurentii Salvii, Stockholm

Linnaeus, C. 1766. Systema Naturae per Regna Tria Naturae. 12 th ed.

López-García, J.M., Blain, H.A., Cuenca-Bescós, G. \& Arsuaga, J.L. 2008. Chronological, environmental, and climatic precisions on the Neanderthal site of the Cova del Gegant (Sitges, Barcelona, Spain). Journal of Human Evolution, 55, 1151-1155; doi: 10.1016/j. jhevol.2008.08.001.

López-García, J.M., Blain, H.A., Cuenca-Bescós, G., Alonso, C., Alonso, S. \& Vaquero, M. 2011. Small vertebrates (Amphibia, Squamata, Mammalia) from the late Pleistocene-Holocene of the Valdavara-1 cave (Galicia, northwestern Spain). Geobios, 44, 253-269; doi: 10.1016/j.geobios.2010.10.001.

López-García, J.M., Blain, H.A., Burjachs, F., Ballesteros, A., Allue, E., Cuevas-Ruiz, G.E., Rivals, F., Blasco, R., Morales, J.I., Rodríguez-Hidalgo, A., Carbonell, E., Serrat, E. \& Rosell, J. 2012. A multidisciplinary approach to reconstructing the south-western European Neanderthals: the contribution of Teixoneres cave (Moià, Barcelona). Quaternary Sciences Review, 43, 33-44; doi: 10.1016/j. quascirev.2012.04.008.

López-García, J.M., Soler, N., Maroto, J., Soler, J., Alcalde, G., Galobart, A., Bennàsar, M. \& Burjachs, F. 2015. Palaeoenvironmental and palaeoclimatic reconstruction of the latest Pleistocene of L'Arbreda cave (Serinyà, Girona, northeastern Iberia) inferred from the small-mammal (insectivore and rodent) assemblages. Palaeogeography Palaeoclimatology, Palaeoecology, 435, 244-253; doi: 10.1016/j.palaeo.2015.06.022.

López-Martínez, N. 1980. Los micromamíferos (Rodentia, Insectivora, Lagomorpha y Chiroptera) del sitio de ocupación achelense de Aridos-1 (Arganda, Madrid). In: Ocupaciones Achelenses en el Valle del Jarama (eds. Santonja, M., López-Martínez, N. \& Pérez-González, A.). Publicaciones de la Excelentísima Diputación de la Provincia de Madrid, 161-202.

López-Martínez, N. \& Ruiz Bustos, A. 1977. Descubrimiento de dos yacimientos del Pleistoceno medio en el karst de la Sierra Alfaguara (Granada). Síntesis estratigráfica de este período en la región Bética. Estudios geológicos, 33, 255-265.

López-Martínez, N. \& Truyols-Santonja, J. 1994. Paleontología. Conceptos y métodos. Ed. Síntesis, Madrid.

Luque-Larena, J.J., Mougeot, F., Vinuela, J., Jareno, D., Arroyo, L., Lambin, X. \& Arroyo, B. 2013. Recent largescale range expansion and outbreaks of the common vole (Microtus arvalis) in NW Spain. Basic and Applied Ecology, 14, 432-441; doi: 10.1016/j.baae.2013.04.006.

Luzi, E., López-García, J.M., Blasco, R., Rivals, F. \& Rosell, J. 2017. Variations in Microtus arvalis and Microtus agrestis (Arvicolinae, Rodentia) Dental Morphologies in an Archaeological Context: the Case of Teixoneres Cave (Late Pleistocene, North-Eastern Iberia). Journal of Mammalian Evolution, 24, 495-503; doi: 10.1007/s10914-016-9355-8.

Machado, J. \& Pérez, L. 2016. Temporal frameworks to approach human behaviour concealed in Middle Palaeolithic palimpsests: a high-resolution example from El Salt Stratigraphic Unit X (Alicante, Spain). Quaternary International, 417, 66-81; doi: 10.1016/j. quaint.2015.11.050.

Mallol, C., Hernández, C.M., Cabanes, D., Sistiaga, A., Machado, J., Rodríguez, A., Pérez, L. \& Galván, B. 2013. The black layer of Middle Paleolithic combustion structures. Interpretation and archaeostratigraphic implications. Journal of Archaeological Science, 40, 2515-2537; doi:10.1016/j.jas.2012.09.017.

Marquina-Blasco, R., Fagoaga, A., Crespo, V.D., RuizSánchez, F.J., Bailon, S., Hernández, C.M. \& Galván, 
B. 2017. Amphibians and squamate reptiles from the stratigraphic unit $\mathrm{Xb}$ of El Salt (Middle Palaeolithic; Alcoy, Spain): palaeoenvironmental and palaeoclimatic implications. Spanish Journal of Palaeontology, 32, 291-312; doi: 10.7203/sjp.32.2.17045.

Martínez-Ortí, A. 1999. Moluscos terrestres testáceos de la Comunidad Valenciana. PhD. Thesis, Universitat de València (unpublished).

Martínez-Ortí, A. 2006. Mollusca. In: Invertebrados Endémicos de la Comunitat Valenciana. Colección Biodiversidad, 14, Generalitat Valenciana, Valencia.

Martínez-Ortí, A. 2014. La malacofauna. In: La Universitat $i$ els seus Entorns. El Carrascal de la Font Roja i La Serra de Mariola. Universitat de València, 236-239.

Martínez-Ortí, A. \& Robles, F. 2003. Moluscos continentales de la Comunidad Valenciana. Colección Biodiversidad, 11, Generalitat Valenciana, Valencia.

McCartney, J. 1802. Lectures on Comparative Anatomy. T.N. Longman \& O. Rees, London.

Mein, P. 1975. Résultats du Groupe de Travail des Vertébrés. In: Report on Activity of the R.C.M.N.S. Working Groups (19711975). IUGS Commission on Stratigraphy, Subcommission on Neogene Stratigraphy Bratislava, 77-81.

Melchior, H.B. 1834. Den danske Stats og Norges Pattedyr. Gyldendal.

Michaux, J. \& Pasquier, L. 1974. Dynamique des populations de mulots (Rodentia, Apodemus) en Europe durant le Quaternaire. Premières données. Bulletin Société Géologique de France, 26, 431-439.

Miller, G.S. 1908. Eighteen new European Voles. Annals and Magazine of Natural History, 1, 100-107.

Milne-Edwards, H. 1874. Recherches pour Servir a l'Histoire Naturelle des Mammifères Comprenant des Considérations sur la Classification de ces Animaux. 1-2. Masson, Paris.

Molina, F.J. 2016. El sílex del Prebético y Cuencas Neógenas en Alicante y sur de Valencia: su caracterización y estudio aplicado al Paleolítico medio. PhD. Thesis, Universidad de Alicante (Unpublished).

Muirhead, L. 1819. Mazology. In: The Edinburgh Encyclopedia, 13, 393-486.

Nadachowski, A. 1982. Late Quaternary Rodents of Poland with Special Reference to Morphotype Dentition Analysis of Voles. Polska Academia Nauk, Panstwowe Wydawnictwo Naukowe, Krakow.

Nadal, J. 1998. Les faunes del Plistocè final-Holocè a la Catalunya Meridional $i$ de Ponent. Interpretacions tafonòmiques i paleoculturals. $\mathrm{PhD}$. Thesis, Universitat de Barcelona (Unpublished).

Oelrich, T.M. 1956. The anatomy of the head of Ctenosaura pectinata (Iguanidae). Miscellaneous Publications of the Museum of Zoology, University of Michigan, 94, 1-122.

Oppel, M. 1811. Die Ordnungen, Familien und Gattungender Reptilien, als Prodrom einer Naturgeschichte derselben. Josep Lindauer, Munich.

Owen, R. 1842. Report on British Fossil Reptiles. Part II. Report of the eleventh meeting of the British Association for the Advancement of Science, held at Plymouth in July 1841, 60-204.
Pallas, P.S. 1799. Novae Species Quadrupedum e Glirium ordine. Erlangen.

Pallas, P.S. 1811. Zoographia Rosso-Asiatica: Sistens Omnium Animalium in Extenso Imperio Rossico, et Adjacentibus Maribus Observatorum Recensionem, Domicilia, Mores et Descriptiones, Anatomen Atque Icones Plurimorum. Petropoli.

Palomo, L.J., Gisbert, J. \& Blanco, J.C. 2007. Atlas y Libro Rojo de los Mamíferos Terrestres de España. Dirección General para la Biodiversidad-SECEM-SECEMU, Madrid.

Pasquier, L. 1974. Dynamique evolutive d'un sous-genre de Muridae, Apodemus (Sylveamus): Etude biometrique des caracteres dentaires de populations fossiles et actuelles d'Europe Occidentale. PhD. Thesis, Université des Sciénces et Téchniques du Languedoc (Unpublished).

Paunesco, A.C. \& Abbassi, M. 2002. Les variations d'Eliomys (Myoxidae, Rodentia) durant le Quaternaire: Aperçu sur des populations du Sud de la France, de Ligurie et d'Espagne. Bulletin du Musée d'anthropologie préhistorique de Monaco, 42, 3-13.

Pelletier, M. 2018. Évolution morphométrique et biogéographie des Léporidés dans les environnements méditerranéens au Pléistocène. Implications socio-économiques pour les sociétés humaines. PhD. Thesis, Unversité Aix-Marseille (unpublished).

Pérez, L., Sanchis, A., Hernández, C.M., Galván, B., Sala, B. \& Mallol, C. 2017. Hearths and bones: an experimental study to explore temporality in archaeological contexts based on taphonomical changes in burnt bones. Journal of Archaeological Science: Reports, 11, 287-309, doi: 10.1016/j.jasrep.2016.11.036.

Poitevin, F., Catalan, J., Fons, R. \& Croset, H. 1986. Biologie évolutive des populations Ouest-Européennes de Crocidures. I: Critères d'identification et repartition biogéographique de Crocidura russula (Hermann, 1780) et Crocidura suaveolens (Pallas 1811). Revue d'écologie, 41, 298-314.

Pujante, A.M., Tapia, G. \& Martínez-López, F. 1998. Los moluscos de los ríos de la Comunidad Valenciana (España). Iberus, 16, 1-19.

Rabeder, G. 1981. Die Arvicoliden (Rodentia, Mammalia) aus dem Pliozän und demälteren Pleistozän von Niederösterreich. Beiträgezur Paläontologie von Österreich, 8, 1-373.

Reumer, J.W.F. 1984. Rusician and early Pleistocene Soricidae (Insectívora, Mammalia) from Tegelen (The Netherlands) and Hungary. Scripta Geologica, 73, 1-173.

Rivas Martínez, S. 1987. Memoria del Mapa de Series de Vegetación de España: 1:400.000. Instituto Nacional para la Conservación de la Naturaleza, Madrid.

Roček, Z. 1984. Lizards (Reptilia, Sauria) from the lower Miocene locality Dolnice (Bohemia, Czechoslovakia). Rozpravy Ceskoslovenské Akademie Ved, Rada Matematickych a prírodnich Ved, 94, 3-69.

Rodríguez-Cintas, A. \& Cabanes, D. 2015. Phytolith and FTIR studies applied to combustion structures: the case of the Middle Paleolithic site of El Salt (Alcoi, Alicante). 
Quaternary International, 431, 16-26; doi: 10.1016/j. quaint.2015.09.043.

Ruiz Bustos, A., Moyano, I.T., Suárez, E.M. \& Gallego, M.A. 1982. Procesos evolutivos durante el Cuaternario medio y superior en las poblaciones de pequeños mamíferos del sur de la Península Ibérica. Condiciones climáticas que implican e importancia bioestratigráfica. Cuadernos de Prehistoria y Arqueología de la Universidad de Granada, 7, 9-35.

Sarrión, I. 1982. Clasificación de la fauna de la Cueva Soterraña (Requena-Valencia). Yacimiento en la Edad del Bronce Valenciano. Lapiaz, 9, 11-20.

Sarrión, I. 1983. La fauna würmiense de la Cueva de San Antón (Villanueva de Viver, Castellón). Spélaion, 2, 29-37.

Sarrión, I. 1990. Apéndice 1. Estudio de la fauna de la Cueva II. Sagvntvm. Papeles del Laboratorio de Arqueología de Valencia, 23, 181-182.

Sarrión, I. 1998. XVII. Clasificación preliminar de la fauna. In: La Lloma de Betxí (Paterna, Valencia). Un Poblado de La Edad de Bronce. Serie de Trabajos Varios, 94 (ed. de Pedro Michó, M.J.). Servicio de Investigación Prehistórica, Diputación Provincial de Valencia, Valencia, 247-260.

Schmidt-Kittler, N. 1987. International Symposium on Mammalian Biostratigraphy and Paleoecology of the European Paleogene. Münchner Geowissenschaftliche Abhandlungen Reihe A: Geologie und Paläontologie, $10,1-312$.

Schrank, F.V.P. 1798. Fauna Boica. Durchgedachte Geschichte der in Baiern Einheimischenund Zahmen Thiere. Erster Band, Stein, Nürnberg.

Sesé, C. 2005. Aportación de los micromamíferos al conocimiento paleoambiental del Pleistoceno Superioren la Región Cantábrica: Nuevos datos y síntesis. In: Neandertales Cantábricos, Estado de la Cuestión. Actas de la Reunión Cientifica. (coords. Montes Barquín, R. \& Lasheras, J.A.). Museo de Altamira, Ministerio de Cultura, Santander, 20, 167-200.

Sesé, C. 2011. Micromamíferos (Erinaceomorfos y Roedores) del final del Pleistoceno Superior y primera parte del Holoceno de Cova Fosca (Alto Maestrazgo, Castellón): Reconstrucción paleoambiental del entorno del yacimiento. Archaeofauna, 20, 119-137.

Sevilla, P. 1988. Estudio paleontológico de los Quirópteros del Cuaternario español. Paleontologia i Evolució, 22, 113-233.

Sistiaga, A., Mallol, C., Galván, B. \& Everett, R. 2014. The Neanderthal meal: A new perspective using faecal biomarkers. PLoS One, 9, 1-6; doi: 10.1371/journal. pone. 0101045.

Szyndlar, Z. 1984. Fossil snakes from Poland. Acta Zoologica Cracoviensia, 28, 1-156.

Thomas, O. 1906. A new vole from Spain. The Annals and magazine of natural history; zoology, botany, and geology, $17,576-577$.

Tormo-Cuñat, C. 2010. Los roedores e insectívoros de los niveles gravetienses de la Cova de les Cendres (Teulada-
Moraria, Alicante). Implicaciones paleoclimáticas. Archivo de Prehistoria Levantina, 28, 47-71.

Tormo-Cuñat, C. \& de Pedro Michó, M.J. 2013. El registro de la fauna de dos yacimientos valencianos de la Edad del Bronce: la Lloma de Betxí y l'altet de Palau. Gestión del ganado, caza y distribución de los restos. In: Animals i Arqueologia Hui: I Jornades d'Arqueozoologia Del Museu de Prehistòria de València (eds. Sanchis Serra, A. \& Pascual Benito, J.L.). Museu Valencià de Prehistòria, Valencia, 257-284.

Tschudi, J.J. 1836. Über ein neues Subgenus von Lacerta Cuv. Isis von Oken, 29, 546-551.

Uetz, P. \& Hošek, J. 2015. The Reptile Database. http://www. reptile-database.org.

Uzquiano, P. 1988. Analyse anthracologique du Tossal de la Roca (Paléolithique Supérieur Final-Épipaléolithique, province d'Alicante, Espagne). In: Wood and archaeology: acts of the European Symposium held at Louvain-laNeuve. Bois et archéologie: actes du Symposium Européen tenu à Louvain-la-Neuve. Louvain-la-Neuve, 209-217.

van der Meulen, A.V. 1973. Middle Pleistocene smaller mammals from the Monte Peglia (Orvieto, Italy), with special reference to the phylogeny of Microtus (Arvicolidae, Rodentia). Quaternaria, 17, 1-144.

van der Weerd, A. 1976. Rodents faunas of the Mio-Pliocene sediments of the Teruel-Alfambra Region, Spain. Utrecht Micropaleontological Bulletins Special Publication, 2, $1-217$.

Vidal-Matutano, P. 2016. Alrededor del fuego: Paisaje, clima y gestión de los recursos leñosos en grupos cazadores-recolectores durante el Paleolítico medio (Alicante, España). $\mathrm{PhD}$. Thesis, Universitat de València (Unpublished).

Vidal-Matutano, P., Pérez-Jordà, G., Hernández, C.M. \& Galván, B. 2018. Macrobotanical evidence (wood charcoal and seeds) from the Middle Palaeolithic site of El Salt, Eastern Iberia: palaeoenvironmental data and plant resources catchment areas. Journal of Archaeological Science, 19, 454-464; doi: 10.1016/j.jasrep.2018.03.032.

Villa, A. \& Delfino, M. 2019. A comparative atlas of the skull osteology of European lizards (Reptilia: Squamata). Zoological Journal of the Linnean Society, 187, 829-928; doi: 10.1093/zoolinnean/zlz035.

Villaverde, V., Román, D., Martínez Valle, R., Pérez Ripoll, M., Badal, E., Bergadà, M., Guillem, P. \& Tormo, C. 2010. El Paleolítico superior en el País Valenciano: Novedades y perspectivas. In: Jornadas Internacionales sobre el Paleolítico Superior Peninsular. Novedades del Siglo XXI. Monografies del SERP, 8, 85-113.

von de Driesch, A. 1975. Sobre los hallazgos de huesos de animales de Los Saladares. In: Los Saladares-71 (eds. Arteaga, O. \& Serna, M.R.). Noticiario Arqueológico Hispánico, Arqueología, 3, 62-66.

von de Driesch, A.V.D. \& Boessneck, J. 1969. Die fauna des Cabezo Redondo bei Villena (Prov. Alicante). Studien uber fruhe Tierknochenfunde von der Iberische Halbinsel, 1, 43-95. 
Waddell, P.J., Okada, N. \& Hasegawa, M. 1999. Towards resolving the interordinal relationships of placental mammals. Systematic Biology, 48, 1-5.

Wagler, J.G. 1832. Isis: 275. In: Mammals Species of the World, a Taxonomical and Geographical Reference (eds. Wilson, D.E. \& Reeder, D.M.). Johns Hopkins University Press, Baltimore, 220-311.

Wagner, J.A. 1840. Beschreibungeinigerneuer Nager. Abhandlungenmathematisch-physische Classe. Königliche Bayerische Akademie der Wissenschafen München, 3, 173-218.
Wilson, D.E., Lacher, T.E., Jr. \& Mittermeier, R.A. (eds.) 2016. Handbook of the Mammals of the World. Vol. 6, Lagomorphs and Rodents I. Lynx Edicions, Barcelona.

Wilson, D.E., Lacher, T.E., Jr. \& Mittermeier, R.A. (eds.) 2017. Handbook of the Mammals of the World. Vol. 7, Rodents II. Lynx Edicions, Barcelona.

Wilson, D.E. \& Mittermeier, R.A. (eds.) 2018. Handbook of the Mammals of the World. Vol. 8, Insectivores, Sloths and Colugos. Lynx Edicions, Barcelona. 
